\title{
SINTAGMAS Y PARADIGMAS EN "LA CONSAGRACION DE LA PRIMAVERA", DE ALEJO CARPENTIER
}

\author{
Rafael Pérez Miguel
}

\begin{abstract}
Time is one of Alejo Carpentier's concerns, and La consagración de la primavera reflects the interest of the Cuban writer in the problem of history. This article intends to show that the syntagmatic structuring of this work follows that of the dialectic materialism of history, and that the paradigmatic structuring in contextualized by several crosscrossing intertexts.
\end{abstract}

La historia ha sido siempre una de las preocupaciones del hombre. La sucesión de acontecimientos -con teorías distintas, desde la concepción filosófica griega de la presencia, la hebrea basada en el pasar, hasta la temporalidad de Newton, Leibniz, Kant, Bergson o Heidegger, precediendo al concepto revolucionario de Einstein - ha sido analizada dado su interés para el ser humano. El devenir siempre le ha interesado; pero hoy, en el siglo XX, el tiempo ha llegado a caracterizar al hombre en su realidad cotidiana, hasta constituirse en la estructura ontológica de la vida. La existencia, el ser de la existencia humana es el tiempo.

Dentro del contexto científico, el estudio temporal ha revestido cada vez mayores proporciones hasta erigirse en la cuarta dimensión, desde Einstein. Y si en las ciencias positivas es un concepto clave, en las ciencias del espíritu - con las últimas interpretaciones de la historia de Spengler, Toynbee, Heidegger - el concepto tiempo ha dejado de ser parte integrante del estudio cosmológico, y se ha convertido en el centro mismo de toda metafísica, en el soporte de su cosmovisión; y en la filosofía marxista-leninista, la historia constituye un capítulo de gran relevancia dentro del análisis de los factores que conforman la sociedad.

Podemos incluso prolongar la línea y descubrir un nuevo modo de sentir el dato temporal en el arte, pues junto a la dislocación del espacio fácilmente comprensible en pintura, se ha dado la del tiempo, que se extiende al propio esquema de la sucesión narrativa en la novelística contemporánea: Proust, Joyce, Kafka, Dos Passos, Gide, Woolf,
Faulkner, García Márquez... caminan por este siglo "en busca del tiempo perdido". De ahí que el tiempo siempre es, en los análisis literarios, un tema de interés, sobre todo, en la narrativa actual.

La mayoría de los críticos que han analizado distintas obras de Alejo Carpentier, han mostrado el interés del cubano por el tema del tiempo. Muchos de ellos han estudiado el carácter "maravillosos", como rasgo distintivo del mismo.

Sin embargo, ¿cuál es la concepción de la historia que aparece en La consagración de la primavera? ¿Presenta una concepción platónica, circular, mítica, "una imagen móvil de la eternidad, número que expresa el movimiento de los astros", como una fuerza que crea las cosas, las destruye y después las vuelve a crear? ¿O es más bien una visión agustiniana, lineal? O como han afirmado algunos críticos, ¿presenta un tiempo "maravilloso"? ¿O se trata de una concepción materialista-dialéctica de la historia, que define los temas narrados destacando las contradicciones objetivas y las opciones del particular momento histórico, o de una postura idealista que se enfrenta con la imposibilidad de acceder al sueño utópico de la sociedad humana perfecta, presentando esos ideales como proyectos defraudados, y en último término negados por una historia repetitiva?

Al responder a estos problemas, no se pretende hacer una filosofía de la historia, ni mucho menos una metafísica del tiempo. Lo que se persigue es hacer un estudio de un modo de entender la historia, con el objeto de ilustrar que La consagración de la primavera refleja una concepción materialista 
dialéctica de la historia. Además, una vez establecidos los sintagmas de esta visión, estudiar metafóricamente la obra, investigar paradigmáticamente la novela para poder establecer el modo peculiar de novelar del escritor cubano, su poética explicitada en sus ensayos sobre crítica literaria.

Cualquier estudio sobre una obra literaria que pretenda mostrar en ella una concepción materialista-dialéctica de la historia, ha de contar, obviamente, en sus objetivos, en el marco teórico-metodológico y en su metodología, con los dos términos nominativos de la hipótesis: materialismo y dialéctica.

Teniendo en cuenta esta dicotomía de términos, unos objetivos apuntarán hacia una cosmovisión materialista de la historia, y otros, hacia una visión dialéctica. En concreto, en cuanto a una concepción materialista de la historia, pretendemos ilustrar los siguientes objetivos:

1. En la novela como en la historia, el modo de producción de los bienes materiales (fuerzas productivas y relaciones de producción) es la base material de la vida de la sociedad. La historia es, ante todo, la historia de los modos de producción que se van sucediendo; la historia es la sucesión de formaciones económicosociales diversas.

2. En el texto literario como en la sociedad, las contradicciones entre las fuerzas productivas y las relaciones de producción son las que explican la ley del proceso de un modo a otro modo de producción. El conflicto es resuelto por el único camino posible: la revolución, que suprime las viejas relaciones de producción y las sustituye por otras nuevas en consonancia con las fuerzas productivas.

3. En la obra literaria como en la realidad, la base económica de la sociedad determina en última instancia la superestructura de la misma sociedad; en consecuencia, todo cambio de la base trae consigo sustitución de la superestructura.

4. En la novela como en la historia, la lucha de clases es la fuerza motriz del desarrollo de la sociedad basada en la explotación. La lucha puede presentar diversas formas: lucha ecónomica, política, ideológica. El Estado es el instrumento político de la dominación de la clase.

5. En el texto literario como en la sociedad, la lucha de clases se pone de manifiesto en épocas de revolución; a través de ésta, unas formaciones económico-sociales son sustituidas por otras.

En cuanto a la concepción dialéctica de la historia, pretendemos mostrar los siguientes objetivos: Así como la historia se halla en estado de perpetuo e ininterrumpido cambio y desarrollo, de la misma manera el mundo narrado de La consagración de la primavera despliega plásticamente este hecho de acuerdo con las siguientes leyes:

1. Ley de la concatenación universal de los fenómenos: es decir, en los hechos en movimiento, se observa una universal interdependencia e infinita concatenación. Aquí, queremos mostrar cómo el cambio es la ley de la historia y de la novela. Y no sólo eso: los distintos aspectos históricos están tan íntimamente relacionados y entre ellos se observa tal interdependencia y concatenación que parecen incidir en un hecho: la Revolución cubana. Es decir, la Revolución cubana nace al impulso de diversas revoluciones contemporáneas, que fueron preparando su camino, aunque no todas de la misma manera: la Revolución rusa y la Guerra civil española tuvieron un sentido especial. Considerando además los factores internos que inciden para el cambio revolucionario en Cuba.

2. Ley del tránsito de los cambios cuantitativos a cualitativos. Es la ley por virtud de la cual los pequeños y al principio imperceptibles cambios cuantitativos, acumulándose gradualmente, rebasan al llegar a cierta fase la medida del objeto y provocan radicales cambios cualitativos, a consecuencia de lo cual cambian los objetos, desaparece la vieja cualidad y surge otra nueva. En concreto, queremos mostrar que esta ley es ley en la novela como en la historia: todas las revoluciones contemporáneas y los pequeños cambios que se fueron gestando en Cuba de acuerdo con su realidad concreta, determinaron el paso de un sistema capitalista a otro socialista. La Revolución cubana trajo como consecuencia cambios radicales, en la base y en la superestructura, que fueron moldeando una sociedad socialista.

3. Ley de la unidad y lucha de los contrarios. Es la ley conforme a la cual todas las cosas, todos los fenómenos y procesos, que poseen internamente lados y tendencias opuestos, luchan entre sí; la lucha de contrarios da un impulso interior al desarrollo y conduce a una agudización de las contradicciones que, al llegar a 
cierta fase, se resuelven mediante la extinción de lo viejo y el nacimiento de lo nuevo. En concreto, queremos mostrar cómo en Cuba los cambios se debieron a una serie de contradicciones externas e internas que se fueron agudizando desde principios del siglo XX, a causa de la oposición de intereses entre dos clases antagónicas: la burguesía cubana amparada por el imperialismo norteamericano, y el proletariado cubano que sufrió las consecuencias.

4. Ley de la negación de la negación. Es la ley cuya acción determina el nexo, la continuidad entre lo negado y lo que niega. En virtud de ella, la negación dialéctica no es una negación pura, gratuita, que rechaza todo el desenvolvimiento anterior, sino la condición misma del desarrollo que mantiene y conserva todo lo positivo de las fases anteriores, que reproduce a un nivel superior algunos rasgos de las fases iniciales $\mathrm{y}$, por último, que tiene en conjunto un carácter progresivo. En concreto, mostraremos cómo en Cuba, según la presentación de la novela, las relaciones de producción han sufrido un cambio hacia un grado superior.

Para ilustrar estas leyes de naturaleza materialista-dialéctica, objetivos de nuestra investigación, debemos sostenernos sobre bases acordes con esta concepción; es decir, debemos sustentarnos sobre fundamentos teórico-metodológicos de carácter materialista-dialéctico. Por ello, elegimos como marco teórico-metodológico el estructuralismo genético de Lucien Goldmann, ya que implica en su concepción este doble carácter (1).

Según Lucien Goldmann, la relación dialéctica entre literatura y sociedad exige un método unitario, que permita no sólo analizar la obra, sino también explicarla. Las coordenadas de este método son la comprensión y la explicación.

La comprensión se entiende como un proceso intelectual, es decir, la descripción de las relaciones constitutivas fundamentales de una estructura significativa (2). Comprender una obra es dilucidar su carácter significativo o el sentido inmanente de su estructuración, es decir, mostrar la obra como estructura con coherencia propia (3). La explicación consiste en insertar el texto en totalidades más amplias (visiones de mundo) y, en última instancia, en la estructura económica y social de un período histórico determinado.
En cuanto a la metodología, seguiremos el siguiente proceso, según las pautas teórico-metodológicas de Lucien Goldmann: Primero, análisis de la obra en sí para establecer la estructura significativa de la obra (comprensión); a un mismo tiempo, en proceso dialéctico con la comprensión, análisis del contexto social, histórico en el que se produce la obra (explicación) (4).

En concreto, seguiremos los siguientes pasos:

a) A través del estudio del argumento de la novela, las isotopías que presenta, el estudio de las macrosecuencias del texto, el análisis de las relaciones paradigmáticas y sintagmáticas, los temas y los personajes, encontraremos la estructura significativa de la obra, el núcleo de significación que aglutina a todos los demás. Este núcleo suele manifestarse en forma de oposición binaria, de dicotomía. En concreto, en La consagración de la primavera, se presentará las siguientes oposiciones:

$\begin{array}{lll}\text { Dialéctica } & \text { vs } & \text { Estatismo } \\ \text { Materialismo } & \text { vs } & \text { Idealismo } \\ \text { Proletariado } & \text { vs } & \text { Burguesía }\end{array}$

b) A partir de estas oposiciones se podrá observar en la novela cómo unos luchan contra el orden establecido; otros luchan por mantenerlo. Todo ello nos mostrará, por un lado, los mitos que constituyen la conciencia real; por el otro, la desmitificación, la desestructuración de los mitos, la búsqueda de valores auténticos, la conciencia posible.

c) Detrás de cada posición, se declara todo un pensamiento ideológico, toda una visión de mundo, que debe ser coherente. Al establecer las oposiciones, se podrá observar si el punto de vista narrativo global de la obra los sanciona positiva o negativamente: así se podrá establecer también la visión de mundo preferente en la novela.

Veremos cómo la revolución es el talón de fondo respecto al cual reacccionan los diferentees personajes, cada cual a su manera. Distinguiremos, así, dos actitudes: los que postulan la revolución como medio necesario para el desarrollo de la sociedad, y los que la niegan. Los que tienen una visión materialista-dialéctica de la realidad, y los que tienen una posición idealista, estática. A pesar de ello, podrán aparecer algunos personajes que no se ajusten a este esquema y requieran algunas explicaciones. Quizá el narador los presente en posición de ruptura con el sistema imperante. De ahí se podrá deducir que la narración está suspendida entre dos momentos históricos e ideológicos que junta, 
sin confundirlos, para poner de manifiesto la contradicción. Así la coherencia de la novela trasciende la incoherencia de los puntos de vista representados por los personajes. Por consiguiente, no se podrá establecer la coherencia de la obra sin insertarla en una estructura histórica que la abarque.

Hay que notar que el tema de la revolución, que nos permitirá entender y explicar La consagración de la primavera, no es un fenómeno independiente.

Es sólo un proceso mucho más general, que rodea la civilización actul que se inicia con la Revolución francesa, y pone en crisis las estructuras económicas, políticas e ideológicas de la burguesía. Conviene, por lo tanto, analizar esta crisis de poder - económico, político e ideológico - para saber si en Cuba se da una cosmovisión, afectada por la ideología burguesa que se desmorona, y por la ideología proletaria que nace, crece y se desarrolla en nuestro siglo, y así poder entrever la unidad de la obra, y situarla en un espacio.

Para analizar esta situación, vamos a tomar como parangón otra novela de Carpentier: El reino de este mundo. Podemos resumir su universo como una estructura circular: oscilación dialéctica entre tiranía y revolución, entendida como ciclo eterno: "Y comprendía, ahora, que el hombre nunca sabe para quién padece y espera. Padece y espera y trabaja para gentes que nunca conocerá, y que a su vez padecerán y esperarán y trabajarán para otros que tampoco serán felices, pues el hombre ansía siempre una felicidad situada más allá de la porción que le es otorgada" (5). Según esto, ila triste historia que le espera a América Latina en la cosmovisión de Carpentier, será un ciclo eterno entre tiranía y revolución?

En La consagración de la primavera se presenta el mismo tema, pero la estructura no es circular, sino lineal. Por eso, en El reino de este mundo los hechos no tienen importancia, pues todo está condenado a la repetición. Mientras que La consagración de la primavera avanza hacia un desenlace, es decir, hay una temporalidad orientada hacia el éxito de la acción, iniciado desde el mismo título de la obra: consagración.

Nos encontramos así ante dos fenómenos esenciales: por una parte, la identidad de tema; por otra, la diferencia radical de estructura; abierta, una; cerrada, la otra. Esto nos hace suponer como hipótesis verosímil que entre 1949, fecha de la primera edición de El reino de este mundo, y 1978, fecha de publicación de La consagración de la primavera, se produjeron acontecimientos que afectaron la estructura política, ideológica y económica de Cuba, que aclaran este cambio de estructura. En caso afirmativo, no hay duda de que el acontecimiento crucial de esa época es la Revolución cubana.

Una vez analizada la novela sintagmáticamente, la volveremos a estudiar repetidas veces siguiendo un procedimiento típico de Carpentier a la hora de elaborar textos literarios: la intertextualidad. Normalmente, Carpentier integra la información sociohistórica al texto propiciando un encuentro de textos que se complementan. La novela resulta así un intertexto, una suma de textos (6). El procedimiento de análisis consistirá en analizar la relación entre los diferentes textos: frente al mundo ficticio se sitúan como instrumentos de análisis otros textos que provienen de la historia. En general, esos textos incorporados al discurso literario contribuyen a situar a los personajes en una época y en una sociedad determinada, ya que para Carpentier no puede existir el acontecimiento aislado sin una variedad de contextos que lo identifiquen; pero, sobre todo, no puede existir un acontecimiento fuera de la historia; de ahí que el contexto histórico, en Carpentier, adquiere gran relevancia en la suma de contextos que él postula a la hora de conformar una obra literaria.

La consagración de la primavera se inscribe, entonces, a partir de hechos históricos y elementos puramente ficticios. Entre ambos se desarrolla un diálogo textual que conforma una obra verosímil, situada entre la historia y la literatura. De ahí que debe ser "abordada como un sistema que no se baste a sí mismo y que debe remitirse a un medio envolvente" (7).

En cuanto a la visión de mundo, La consagración de la primavera se destaca como un ejemplo claro de la concepción materialista-dialéctica de la historia. En la trama se narra la historia de las revoluciones contemporáneas, comenzando en la francesa y acabando en la cubana. En el plano de la estructura, también puede servir de modelo, en la medida que la concepción del mundo narrado y el punto de vista de los protagonistas, presentan una visión materialista-dialéctica. Esta novela, así, abre nuevas posibilidades a la colectividad como centro de organización, en lugar de las estructuras individuales a las que estaba acostumbrada la narrativa tradicional. De ahí que inscribir La consagración de la primavera en el materialismo dialéctico como ideología es señalar la posibilidad de un tipo de creación artística, es determinar su marco categorial. 
La fábula o argumento constituye un elemento fundamental para establecer la estructura de una obra, ya que la acción novelesca, desarrollándose en el tiempo, representa el flujo y la urdimbre de la vida misma. La historia narrada, como observa Foster, constituye la espina dorsal de la novela, y representa lá supervivencia, en una forma artística, de una actitud ancestral del hombre: la actitud de curiosidad que impele al hombre a oír una narración (8). Según Bourneuf y Ouellet, el argumento de una novela se basa en la noción fundamental de movimiento, de cambio, a partir de una situación dada y bajo la influencia de ciertas fuerzas (9).

La fábula de La consagración de la primavera se puede sintetizar de la siguiente manera: Vera, una bailarina rusa, que ha huido de una revolución (la revolución rusa), viaja hacia España para visitar a su amante Jean-Claude, quien muere más tarde en las filas de las Brigadas Internacionales durante la Guerra civil española. Allí conoce a Enrique, un joven arquitecto cubano que lucha en España en contra del Gobierno de Burgos, y que al alcabar la guerra busca a Vera en París. Ambos, al avecinarse la Segunda Guerra Mundial, huyen hacia Cuba, donde participan en el proceso revolucionario que allí se realiza.

Podemos afirmar entonces que en la novela se dan dos líneas de acción: la de Vera y la de Enrique. Sin embargo, sus destinos se unen, primero de una manera superficial, pero más tarde se forma definitiva “consagrados" en la Revolución cubana. Luego la Revolución cubana se presenta - el título de la novela así lo manifiesta - como la culminación de una serie de revoluciones cuyo origen debe buscarse en la Revolución francesa. No obstante (Barthes observa que el principio y el final de una obra es fundamental para determinar su estructura) (10), el final de La consagración de la primavera insinúa que la historia de las revoluciones en este siglo no ha acabado. La Revolución cubana no es sino el "boceto" de otra serie de revoluciones que seguirán:

"Los ballets (metáfora de la revolución) no pasaron hasta ahora, de ser tímidos bocetos de lo que llegarán a ser algún día" (p. 576). Aunque la frase escrita en 1760 por Noverre en Cartas sobre la danza se cumple proféticamente en la Revolución cubana; sin embargo, colocada al final de la novela, cuando ya la Revolución cubana es un hecho, deja entrever la posibilidad de que la Revolución cubana es sólo el boceto de futuras revoluciones que se darán en años venideros.
Siguiendo el pensamiento de Barthes sobre la importancia del principio y del final en el análisis de las obras literarias, encontramos la siguiente estructura. La consagración de la primavera comienza así:

"El suelo. A ras del suelo. Hasta ahora sólo he vivido a ras del suelo, mirando al suelo $-1 \ldots 2 \ldots 3 \ldots-$, atenta al suelo -1 yyý 2 yyý $3 \ldots-,(\ldots)$ Pero ahora, tras de una noche en tinieblas y llano, el suelo, por primera vez, se me levanta, se para, se detiene, me cierra un paisaje de albas, mostrándoseme en Alta Presencia de Montañas. Un sol, que aún no veo..." (11).

Este comienzo de la novela nos introduce en los temas principales de la novela: albas, soles, movimiento, materia. Las últimas frases de la novela le corresponden:

"Cayó la noche, se fueron los dos, y 1, 2, 3, 1 yyyyý 2 yyyyý 3 , me conté a mí misma cuando quedé sola, volviendo a colocar la zapatilla de Anna Púvlova en su pequeña vitrina, junto a mi preciosa edición de las Cartas sobre la danza donde el maestro Noverre había escrito en 1760: "Los ballets no pasaron, hasta ahora, de ser tímidos bocetos de lo que llegarán a ser algún día”. 1, 2, 3, 1 yyyyyý 2 yyyyyý $3 . . . ”($ p. 576).

Entre estas dos noches que delimitan el relato, se ha cumplido el ciclo del movimiento, la noche se ha convertido en luz, día, y el sol ha alcanzado su cenit en Cuba.

Con el fin de encontrar una estructura significativa coherente del texto (cuando todos los elementos de significación, en todos los niveles, se ordenan hasta el punto de producir una significación global que los abarca y los hace inteligibles), Greimas ha afirmado que la isotopía es el elemento que puede dar mayor coherencia, el que da mayor sentido a la totalidad, el que explica mejor la estructura de un texto. El concepto de estructura, para Greimas, exige la presencia de dos términos y la relación entre ellos existente. Dicha relación impone la necesidad de una doble constatación, expresada en la siguiente forma: a) Para que dos términos-objeto puedan ser captados a la vez, es necesario que posean algo en común; b) Para que dos términos-objeto puedan ser distinguidos es necesario que sean diferentes, del modo que fuere. La relación pone, entonces, de manifiesto una doble naturaleza: es a la vez conjunción y disjunción (12).

Realicemos una lectura "isotópica" (13) de $\mathrm{La}$ consagración de la primavera en el sentido etimológico que tiene la palabra isotopía "mismo lugar", con el objeto de esclarecer su estructura. Al establecer los lugares en donde suceden los acontecimientos, los lugares por donde discurre el viaje de los personajes de la novela, encontramos el siguiente itinerario: 


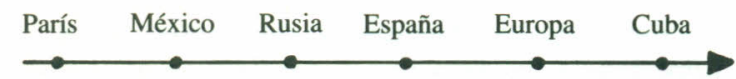

A primera vista parece que el elemento unificador de la isotopía no existe en la estructura superficial; sin embargo, en la estructura profunda encontramos un elemento ordenador de todas esas aparentes divergencias:

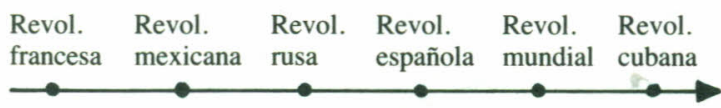

Por tanto, la Revolución es el clasema en común que unifica la isotopía. La conjunción es la Revolución; la disjunción, la localización geográfica de esa revolución. De aquí se desprende la conclusión de que en toda revolución debe haber un elemento unitario, y otro diferenciador. Es decir, las revoluciones son conjuntivas y disjuntivas de acuerdo a factores subjetivos y objetivos en un momento y lugar específicos.

A partir de este primer esclarecimiento de la novela de naturaleza semántica, estableceremos ahora las secuencias (14) y macrosecuencias de la obra, elementos estructurales básicos de toda narración.

Ya que el sentido o función de todo elemento de una obra es su posibilidad de entrar en correlación con otros elementos y con la obra en su totalidad, al realizar el estudio de los núcleos de las secuencias en relación con los demás núcleos de la novela en su totalidad, llegamos al siguiente organigrama de La consagración de la primavera:

\begin{tabular}{l|l|l|l|l|l}
\hline $\begin{array}{l}\text { Revol. } \\
\text { francesa }\end{array}$ & $\begin{array}{l}\text { Revol. } \\
\text { mexicana }\end{array}$ & $\begin{array}{l}\text { Revol. } \\
\text { rusa }\end{array}$ & $\begin{array}{l}\text { Revol. } \\
\text { española }\end{array}$ & $\begin{array}{l}\text { Revol. } \\
\text { mundial }\end{array}$ & $\begin{array}{l}\text { Revol. } \\
\text { cubana }\end{array}$ \\
\hline
\end{tabular}

Para encontrar las unidades narrativas de sentido (secuencias y macrosecuencias), hemos procedido a la segmentación de la obra en episodios, acontecimientos que aparecen en la novela de manera sintagmática. ¿Qué hechos se dan en la novela? Guerras, revoluciones. Este motivo (15) dominante, central, adquiere cierto matiz de leitmotiv (16). Su misma naturaleza repetitiva incide en la estructura de la novela al dejar abierta la posibilidad de nuevas revoluciones - nuevas repeticiones - después de la Revolución cubana. Por eso el organigrama aparece abierto al principio y al final acorde a su naturaleza dialéctica.

Es importante notar que - como las secuencias - cada revolución tiene núcleos que abren, continúan y finalizan las revoluciones. Es decir, cada revolución presenta un principio, medio y fin, aunque no de modo separado de las demás revoluciones. Pues toda revolución nace, crece y finaliza basada en factores subjetivos y objetivos que la hacen original; sin embargo, al mismo tiempo, ese proceso único, irrepetible, sólo constituye un paso más en el movimiento revolucionario mundial.

En consecuencia, proponemos el siguiente esquema que permite visualizar lo afirmado:

Revolución mundial: (Paso del capitalismo al socialismo) MACROSECUENCIA

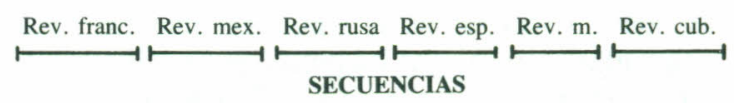

Obsérvese cómo en el desarrollo se sigue un orden lógico cronológico. Con ello se insiste en la relación entre las diversas revoluciones: cada una de ellas es causa de las siguientes y efecto de las anteriores. Así se construye la dialéctica de la revolución: los hechos aislados no existen en esta visión de mundo; la concatenación es la ley esencial de la historia narrada.

Si la revolución es el leitmotiv que se repite insistentemente a través de la fábula, el medio, en la novela, para trasladarse por las diversas revoluciones, es el viaje de sus personajes. El viaje da a la novela su argumento y su principio de unidad. Vera y Enrique se desplazan a través de su época (revoluciones del siglo XX), y al final de su historia, los hechos hacen exclamar a Vera: "iqué accidentado y difícil me fue el camino!” (p. 576). Sin embargo, la seguridad de la llegada imprime a las acciones un carácter determinista: "Puede usted estar segura de llegar, con tal de que camine durante un tiempo bastante largo", dijo a Alice el Gato de Lewis Carrol (p. 576).

Por eso, Vera reinstalada en su casa, piensa en "el misterioso determinismo que rige la prodigiosa urdimbre de destinos distintos, convergentes, paralelos o encontrados, que, llevados por un inapelable mecanismo de posibilidades, acaban por incidir en razón de acontecimientos totalmente ajenos a la voluntad de cada cual" (p. 575).

En resumen, al analizar la estructura de la novela horizontalmente, sintagmáticamente, en cuanto sucesión de episodios, hemos encontrado una dimensión diacrónica, esencialmente dinámica, es decir, el devenir histórico, la revolución como elemento 
unificador de la novela; hemos observado los entornos, los elementos que siguen y preceden a la revolución, pues describir no sólo es determinar las unidades constituyentes, sino también observar el orden de su sucesión. De esta manera, hemos llegado a determinar el primer término de la estructura dialéctica de la novela: Revolución.

Si el cambio, la revolución, es la ley de la novela, sin embargo hay hechos, posturas de los personajes, ideologías que quieren contrarrestar ese movimiento ascendente de la humanidad: es la cosmovisión burguesa sobre la revolución.

El padre de Vera durante los días de la época revolucionaria en Rusia, percibe una serie de "desórdenes" que no están acordes con su "orden", visión de mundo: "No se puede contar con nada ni creer en nada" (p. 476). Al no vislumbrar la naturaleza revolucionaria del cambio, prefiere el "orden" que había regido durante el Gobierno de los Zares. Y al ver empeorar la situación, envía giros considerables a bancos de Londres y París para engrosar las grandes sumas que tenía en bancos suizos, bajo palabra de adquirir existencias de paños para una tienda imaginaria, luego de haberles enviado telegramas, por otra vía, recomendándoles que le guardaran los fondos hasta nueva orden ( $\mathrm{p}$. 484). Preparado así el camino, decide marchar a Londres, pues "Aquí no hay modo de hacer nada. Esto es el caos. no se respeta nada. La propiedad ha perdido todo valor. El comercio está agonizando. La chusma se ha adueñado de todo. La gente decente, como nosotros, no tiene más remedio que emigrar" (p. 485).

En Rusia, no sólo el padre de Vera disiente de tales "desórdenes": "Los corredores de bolsa, los negociantes, los abogados, los representantes del comercio, y, sobre todo, las bailarinas, maldicen el desorden actual" (p. 481). Ante esta situación de caos, y no percibiéndose cambio alguno: “...la vida sigue, prosigue, en un constante apetito de placeres (...) Mi padre dice que los restaurantes de lujo están repletos..." (p. 481). No obstante, los círculos oficiales afirman que "todo volverá pronto al orden" (p. 481), pues la Guerra la tenemos ganada (p. 496).

Pasados los años, todavía Madame Christine hablaba en París a Vera sobre los horrores del allá (mercado negro, privaciones, descontento de campesinos, sublevaciones de obreros), y cómo había logrado escapar de aquel infierno. No obstante, en su corazón anidaba la esperanza de volver pronto a celebrar las Grandes Pascuas Rusas en Moscú, volver a la situación que imperaba antes de la revolución (pp. 496-497). Este modo burgués de ver la realidad, que aboga por el orden establecido, está en contraposición con la visión de mundo que exige la revolución como ley de la historia.

Si en Rusia aparece una visión burguesa respecto a los acontecimientos que se desarrollan, en España esa cosmovisión está representada por la palabra "Burgos" y todo lo que significa: Francisco Franco, Millán Astray, Legión Cóndor, fascistas alemanes e italianos. Todo ello en lucha contra las ideas revolucionarias representadas por el Gobierno de Madrid.

Burgos representa "los de la derecha" (p. 97), "los facciosos" (p. 96); Madrid "los de la izquierda" (p. 97), los "de este lado de la barrera" (p. 27), los que "pelean por algo" (p. 30). Esta dicotomía es interpretada por Enrique así: "todos aquellos que, ufanos de haber edificado vastas y hermosas capitales ultramarinas, se complacían en decir que Madrid era una aldea grande, detenida en un pasado verbenero y localista, se volvían apasionados defensores del Madrid de hoy, visto como realidad y símbolo opuesto a Burgos, que le olía ahora, retrospectivamente, a carnes de indios quemados y sangres derramadas por Conquistadores feroces..." (p. 98). Y Vera lo reinterpreta de esta manera: "Se era rojillo, o se era falangista. Se estaba con la República o se estaba con Burgos..." (p. 128).

El punto de vista burgués durante la Segunda Guerra Mundial está caracterizado en la novela por la lucha contra el expansionismo del comunismo ruso, verdadero Fantasma, peligro que amenaza la "vieja, hermosa, admirable Cultura Occidental, heredera de la Cultura Hélenica, de la Cultura Latina, con sus magníficas, imperecederas Libertades" (p. 265).

Durante la Revolución cubana, el Gobierno se alía con la burguesía para que en servicio de la ciudadanía, el hogar y la familia, poder torturar, encarcelar y matar a todos aquellos que se levantaran contra el "orden" establecido (pp. 394-5). A pesar de ello, se llegó a la Revolución, aunque el camino no fue fácil. Hubo que luchar contra enemigos internos y externos: la oligarquía y el imperialismo yanky. Todavía después de la revolución política la burguesía reacciona para afirmar que el nuevo orden sería una hecatombe, el fin del mundo (p. 534). Para evitarlo, organiza la contrarrevolución promoviendo incendioss, muertes, accidentes (p. 547). Pero sobre todo el desembarco en Playa Girón. 
En resumen, con la Revolución aparece la contrarrevolución en la novela, es decir, una visión estática de percibir la realidad. Así la dicotomía fundamental sobre la que se estructura la novela es:

\section{Dialéctica vs Estatismo \\ Revolución vs Contrarrevolución}

A partir de estas oposicioness, se observa en la novela cómo unos personajes luchan por mantener el orden establecido; mientras que los hechos, llevados a cabo por los hombres, muestran que la ley de la vida es el cambio. Los primeros defienden los mitos que constituyen la conciencia real; su universo funciona como un coto cerrado; para ellos no hay cambio, sólo pequeñas adaptaciones a la

vida. Los segundos desestructuran esos mitos y presentan los valores auténticos, la conciencia posible; se oponen a la mentalidad del burgués al tomar iniciativas de progreso.

La oposición de las parejas manifiesta en verdad dos realidades diferentes, aunque relacionadas: la burguesía y su opuesto el proletariado. Herederos degradados de la actitud prometeica, los burgueses están petrificados en un presente, destinado a enmascarar el avance del tiempo, mientras que los proletarios indican la inminencia de una transformación: paso del capitalismo al socialismo. La posición de Vera y Enrique, al final de la novela, dejan fuera de toda duda la ambigüedad: pertenecen ya a una nueva generación de hombres cuyos valores serán los mismos que los de tantos otros que han luchado por la transformación en el mundo; mientras que la Condesa forma el retrato de los personajes pasados a la historia. Hasta en el modo de vestir se manifiesta: mientras los guerrilleros de Castro eran "barbudos", la Condesa se destaca “...por el lujo de los atuendos, el relumbre de las joyas, la gracia de los peinados..." (p. 31). En ellos se observa una silueta pasada de moda" con un siglo de retraso" al de La guerra y la paz, según Vera.

Debemos comprender que esta oposición de personajes nos remite a dos sistemas históricos, políticos y sociales: el capitalismo y el socialismo, que nos trasladan inconfundiblemente a dos épocas. La primera, ligada a la caída del sistema antiguo, muestra al burgués y su mundo que se hunde. La segunda está ligada a una nueva generación de hombres: los proletarios. Los primeros arrastran una serie de mitos, que los segundos intentan cambiar.
Los mitos que aparecen en La consagración de la primavera, en relación a la concepción dialéctica de la historia, se reducen a los siguientes:

- En la vida lo importante es el Orden, la Ley.

- La gente que cumple la Ley es decente; los revolucionarios son chusma.

- El comunismo es un Fantasma, peligro que amenaza al Occidente, los Valores de Occidente, las Libertades de Occidente.

- La Libertad es el valor supremo.

- La contrarrevolución es un medio para evitar el cambio.

En contraposición, se presenta la desmitificación, pues en la novela se cree que:

_ El "desorden" es la Ley de la vida.

- La gente que no cumple la Ley es revolucionaria.

- El Comunismo, único camino para el cambio.

- Postula un nuevo tipo de libertad.

- La Revolución es necesaria para propiciar el cambio.

De esta manera, la Revolución pone en movimiento lo fijo, invierte la jerarquía de valores, y desmitifica la afirmación burguesa repetida, y aun convencida, de la excelencia de sus costumbres, de sus instituciones, de su superioridad cultural.

La visión de mundo preferente de la novela, la que aparece más coherente de acuerdo a los ideales de la época, con la que más simpatizan los personajes principales de la novela, con la que se identifica la multitud, el pueblo de La consagración de la primavera, es una visión dialéctica de la historia.

El texto que mejor prueba esta afirmación es aquel en que aparece Vera - puño en alto - gritando junto al pueblo: ¡Viva la Revolución!: “Abrí todas las ventanas de la casa. Las calles estaban llenas de una multitud jubilosa que parecía haber recobrado voces harto tiempo calladas. Frente a mí pasaron algunos con el puño en alto: "¡Viva la Revolución!”. - “¡Viva!” - dije. —“Más alto: no se oye" - me dijo el médico. - "¡Viva la Revolución!" - grité, esta vez alzando una mano abierta, blanda, indecisa. - "Así, no. Es con el puño cerrado. Fíjese: haga como yo". Acabé por leṿantar el puño a la altura de la sien, recordando que así hacían Gaspar y Enrique - y acaso también Calixto, ahora. - "Bien" - dijo el médico: "A la una, 
a las dos, a las tres: ¡Viva la Revolución!”-clamamos los dos al unísono. - “¡Viva!” respondió la calle entera..." (p. 510).

La novela presenta así una concepción dialéctica de la historia que exige el devenir, la revolución como ley fundamental de la vida. Las leyes del mundo narrativo, por eso, son las leyes del movimiento: los hechos sólo pueden explicarse cuando se les considera en su proceso de nacimiento, desarrollo y muerte; proceso que se debe a las contradicciones internas de los hechos, a la lucha de clases como fuerza motriz que hace avanzar toda sociedad basada en la explotación; mientras la clase dominante intenta mantener su "statu quo", su situación privilegiada, las demás clases sociales luchan por derrocarla hasta que lo consiguen, sobre todo, a través de la revolución social.

Roland Bourneuf y Réal Ouellet definen la acción de la novela como "el juego de fuerzas opuestas o convergentes presentes en una obra. Cada momento de la acción constituye una situación conflictiva en la que los personajes se persiguen, se alían o se enfrentan" (17).

Greimas ha sido uno de los teóricos que se ha preocupado en determinar cuáles son estas relaciones recíprocas y el modo de existencia en común de los actantes de un microuniverso; para ello ha establecido el siguiente esquema, tomando como punto de vista la ideología marxista:

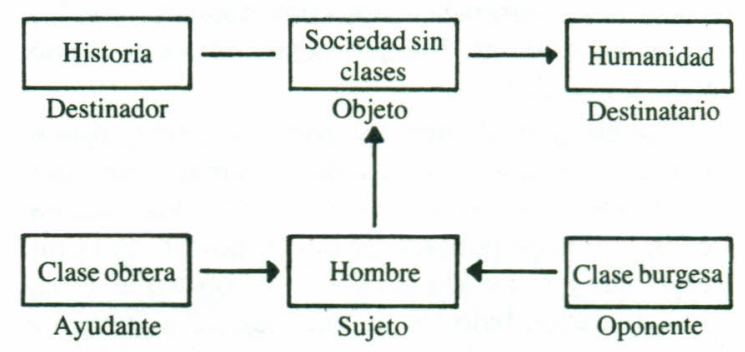

El sujeto-hombre persigue como objeto fundamental de su vida una sociedad sin clases (conciencia posible), cuyo destinador es la Historia y el destinatario el propio hombre. En la lucha por conseguirlo encuentra un aliado que lo ayuda, y un oponente que se le enfrenta: clase obrera y clase burguesa, respectivamente (18).

En La consagración de la primavera, los personajes se muestran irreductiblemente pertenecientes a una de esas dos clases. Sólo Vera y Enrique que comienzan su vida en una clase social, son capaces - a partir de los hechos que viven - de pasar de una clase a otra; los demás "nacen y mueren" en la misma clase:

\section{Proletarios}

Paco: tabernero

Jean-Claude Lefevre: marxista militante, profesor

Venancio: criado

Cristina: criada

Leonarda: criada

Atilio: criado

Ada: musicóloga, amante de Enrique

Gaspar Blanco: trompetista, marxista

Django Reinhardt: músico

Naná: hermana de Django

Jacinto: chófer

Gian Carlo: lucha en Brigadas Internacionales

Paul Robeson: cantante

Hemingway: escritor

Constante: barmann

Alumnos de Vera: Hermenegildo, Valerio, Filiberto, Sergio, Mirta, Calixto

Susana: santera

Camila: criada

José: Cantinero

Doctor de Barbacoa

Pablo: criado

Pedrito: trabaja en un bar

\section{Burgueses}

Madame Labroussi-Tissier: modista José Antonio: publicista

Hans: representante de Bayer

Capitolina: prima de Vera

Sacha: capitán de artillería

Liuba, Olga: bailarinas

Estelita: prima de Enrique

Teresa: tía de Enrique

Madame Christine: profesora de ballet

Laurent: negociante, esposo de Olga

Marina: empresaria de burdeles

Dimitri: sobrino de Vera

Alumnas de Vera

La Condesa

El Conde

Vladimiro: padre de Vera

Antonia Marcé: bailarina

Irene: amante de Enrique

Coronel de Brasil: representante de ballet

Fulgencio Batista: político

Gerardo Machado: político

Franco, Hitler, Mussolini 
Si se observa las características comunes de los personajes, hallamos que la mayoría de los proletarios son marxistas, criados o dependientes; mientras que los burgueses son comerciantes, condes, políticos, es decir, los que tienen el poder económico y. el político.

Por un lado, dentro del grupo de proletarios se hallan los criados de los condes, los marxistas comprometidos, los asalariados junto a “...los centenares de miles de pobladores del "cinturón de la miseria" que circundaba la capital, o construían covachas de cartón bajo los puentes tendidos sobre sus quebradas pululantes de ratas y alimañas, mientras legiones de niños dispersos por las calles vivían de lo que les ofreciera el azar" (p. 536), que observa Enrique alrededor de Caracas. Todos ellos suman "...un conjunto, un todo, una colectividad, parte, a su vez, de una colectividad mucho más cuantiosa y universal..." (p. 120), es decir, la clase proletaria, unida entre sí por lazos de dependencia respecto de la clase burguesa.

En frente y en contraposición, hallamos a Madame Labroussi-Tissier "la modista en boga" (p. 38); José Antonio, publicista, "reaccionario de mierda" (p. 338), según Gaspar; el catire Hans, que trabaja para el Gobierno alemán “....porque no me quedaba más remedio" (pp. 109-110); toda la familia de Vera y Enrique; Laurent "un genio de los negocios" (p. 364); Marina, empresaria de burdeles en La Habana (p. 419); además, los políticos reaccionarios: Franco, Batista, Machado...

Según Gaspar, ellos componen "el orden burgués”, y según Enrique “...el sistema capitalista, con sus principios, sus instituciones, sus jerarquías, su concepto de familia..." (p. 165). Son los banqueros, hacendados, negociantes; la gente de dinero, dentro de las ciudades mercantiles y burguesas, cuidadosa de apariencias, a la vez hipócrita y "decente” (p. 205), según Enrique. Es “...la gente presumida de abolengo (como mi tía) o consciente de haber amasado fortunas a costas de muchos esfuerzos y quebrantos (...) politicastros enriquecidos por mágica operación de peculado, saqueos de fondos públicos, turbias componendas y sucios negocios. Los altos representantes de la banca y de la industria, del azúcar y de la bolsa, adheridos a sus teletipos, en perenne relación con los mercados mundiales, sumidos en la tecleante sinfonía de las máquinas calculadoras, puestos los ojos en pizarras de cotizaciones, suscritos a veinte periódicos financieros (...) explotadores de hombres, usufructuarios de latifundios y plusvalías, dueños de minas que jamás habían visitado, de cañaverales abiertos de horizonte a horizonte (...) con cuentas en New York, en Boston, en Suiza" (p. 226), según Enrique. Gaspar es el personaje que explica el común denominador de todos estos diferentes elementos: “...mis... - enemigos de clase son millones y millones, pero, en realidad: uno solo. Porque siempre es el mismo. Alemán, italiano, franquista allá, yanquí aquí: estacas del mismo palo. Fascismo, colonialismo, tercera solución, monopolios, capitalismo, latifundistas, burgueses: el mismo perro con distintos collares" (p. 254).

En resumen, los personajes de la novela se estructuran de acuerdo con la siguiente dicotomía:

$$
\text { burguesía vs proletariado }
$$

La oposición de estas parejas de personajes manifiesta dos realidades distintas, pero relacionadas: los unos defienden los mitos que constituyen la zonciencia real, una visión idealista de la historia; los segundos presentan los valores auténticos, la conciencia posible, una visión materialista de la historia. Esta dicotomía remite a dos sistemas históricos diferentes: el capitalismo y el socialismo. Los primeros representan un mundo en decadencia; los segundos, una sociedad naciente.

Los mitos que aparacen en La consagración de la primavera, en relación con la concepción materialista de la historia, se pueden reducir a los siguientes:

- La situación económica imperante en el mundo narrado se debe, ante todo, a los muchos esfuerzos, a la "laboriosidad, empeño, tesón" (p. 226) de la clase burguesa, que durante siglos ha trabajado hasta lograr lo que hoy tiene.

- Esta clase social está considerada como la Sociedad (p. 37), es decir, forman el clan de las personas "decentes".

- En este mundo “....se tiene por noción fundamental que toda Idea ajena a la Idea de poseer no es Idea válida; donde se cree que sólo son reales y útiles los acontecimientos que actúan en nuestro provecho..." (p. 44).

- Dios es el personaje central de la historia: él es quien mueve y determina todos los acontecimientos históricos. El es, en definitiva, quien salvará a las naciones: "Dios salvará a Rusia como la ha salvado tantas veces ya" (p. 485).

En contraposición, la novela presenta la dismitificación pues se cree que "el trabajo" acumulado de siglos, la "Sociedad", el dinero, "Dios", sólo 
han sido instrumentos para explotar al ser humano; estos mitos han ocultado la verdadera naturaleza de las relaciones entre los seres humanos.

Por eso, la visión de mundo preferente en la novela, la que aparece más coherente con los ideales de la época, con la que simpatizan los personajes principales de la novela, con la que se identifica el pueblo de La consagración de la primavera, es una visión materialista de la historia. El texto que mejor prueba esta afirmación es el discurso del personaje Fidel Castro en el acto del sepelio de las víctimas del bombardeo del 16 de abril, que Vera incorpora al espacio novelesco en forma de discurso, escuchado por radio: " $¡ N o s o t r o s$, con nuestra Revolución, no sólo estamos erradicando la explotación de una nación por otra nación, sino también la explotación de unos hombres por otros hombres! ¡Nosotros hemos condenado la explotación del hombre por el hombre, y también erradicaremos en nuestra patria, la explotación del hombre por el hombre! ...Compañeros obreros y campesinos: ésta es la Revolución socialista y democrática de los humildes, con los humildes y para los humildes.

Y para esta Revolución de los humildes, por los humildes y para los humildes, estamos dispuestos a dar la vida" (p. 575).

De ahí que la novela se estructura también de acuerdo con la siguiente dicotomía:

\section{materialismo vs idealismo}

Por un lado, la concepción idealista de la histor ia que ha contado siempre con el decidido apoyo de las clases explotadoras, interesadas en ocultar las verdaderas causas de la desigualdad social y económica.

Por otro lado, la concepción materialista de la historia que muestra que en la sociedad no obra ninguna fuerza misteriosa del más allá: los hombres son quienes crean su historia, de conformidad con las condiciones objetivas materiales que heredan del pasado. "No es la conciencia la que determina la vida, sino la vida la que determina la conciencia", según la tesis central de esta concepción. De donde se deduce que la base económica (modo de producción) es la base material de la vida de la sociedad que, en definitiva, determina la superestructura; así, todo cambio en la base traerá consigo cambio en la superestructura. De ahí que la historia es, ante todo, la historia de los modos de producción que se van sucediendo.
Asimismo, esta visión materialista cree que son las contradiciones entre las fuerzas productivas y las relaciones de producción las que explican este proceso de un modo de producción a otro, cuyo conflicto es resuelto a través de la Revolución.

Igualmente, piensa que la lucha de clases es la fuerza motriz del desarrollo de la sociedad, que se pone de manifiesto, sobre todo, en épocas de revolución social.

Saussure establece que las relaciones entre los elementos pueden ser de dos tipos: sintagmáticas y asociativas (19). Las primeras son relaciones entre elementos copresentes, "in praesentia"; son relaciones metonímicas, "horizontales" en cuanto sucesión de episodios, motivos, personajes; son relaciones diacrónicas, esencialmente dinámicas, que enfocan el cambio, el desarrollo, el tiempo cronológico, el devenir histórico. Describir un sintagma no sólo es determinar las unidades que lo constituyen, sino también observar el orden de su sucesión.

Las relaciones asociativas - también llamadas paradigmáticas - son relaciones entre elementos ausentes, "in absentia"; son relaciones metafóricas, "verticales", sincrónicas, que enfocan el tiempo "detenido.

$\mathrm{Al}$ analizar los aspectos dialécticos de La consagración de la primavera, hemos mostrado cómo el mundo narrado de esta novela está conformado por hechos históricos relevantes - revoluciones del siglo XX - estructuradas diacrónicamente. Teniendo en cuenta que la novela no es sólo un texto de historia de las revoluciones, ¿no podremos encontrar en ella otros elementos históricos y no históricos que estén en relación paradigmática con la isotopía histórica analizada, aunque ellos estén desarrollados sintagmáticamente en la novela, conformando verdaderas metáforas de la revolución?

Es cierto que Carpentier en sus obras, propiciando encuentros de textos que se complementan, confronta los hechos históricos con los contenidos novelescos para iluminar la organización del texto literario y la situación socio-histórica que describe, pues para Carpentier no puede existir un hecho fuera de la historia (20). Sin embargo, no es menos cierto que para el creador cubano - además del contexto histórico-, la novela dialoga con otros con - textos de una época que deben tenerse en cuenta a la hora del análisis de una obra literaria, los cuales van a descubrir las vivencias, las palpitaciones, la sangre, los gemidos, los clamores de nuestra época, y son los que van a definir al hombre 
actual. Es decir, Carpentier da vida a los personajes, acontecimientos, dentro de un contexto que particulariza nuestro mundo, para ofrecer así una visión totalizadora de la época que nos ha tocado vivir, para indagar en su proceso en sus múltiples direcciones. La novela no puede llegar a las abstracciones que le son posible a la historia; necesita representar su mundo antes que explicarlo, con imágenes concatenadas, con contextos que permitan hacer de la novela un mundo más verosímil.

Este tipo de elaboración de las novelas de Carpentier exige una lectura que no puede quedarse en la mera superficie del texto. Hay que hacer un examen a fondo de la narración si queremos desentrañar su significación. Hay que leer la obra también paradigmáticamente, "trabajar metafóricamente" como le dice Enrique a Martínez de Hoz: "Metáfora: 'Figura de retórica por la cual se transporta el sentido de una palabra a otra, mediante una comparación mental” ...“¿¿Entiendes?” -“No mucho”. "Mediante una comparación mental" -repetí: "Yo sí me entiendo". Instalaba mi dominio particular en el contexto de mi dominio geográfico e histórico. Mis dominios" (pp. 552-553).

El objetivo de este aparato es, precisamente, analizar los contextos de la revolución, estudiar metafóricamente la novela, investigar paradigmáticamente la obra.

\section{A. La naturaleza}

El mundo narrado de la novela está conformado, preferentemente, por el cosmos socio-histórico del siglo XX: una serie de revoluciones, que se repiten con cierta persistencia. En relación paradigmática, el mundo natural observa también en la obra regularidad y constancia.

El espacio novelesco se conforma simbólicamente con elementos del mundo natural: primavera, el día, el árbol y la tierra madre.

Desde el mismo título de la novela, la primavera se constituye en elemento significativo. Allí, se refiere al ballet de Strawinsky, y denota el mito primaveral (aspecto que analizaremos más adelante); aquí, estudiaremos la primavera desde el punto de vista temporal.

Así como los personajes, y sobre todo Enrique y Vera, se desplazan de revolución a revolución, de la misma manera lo hacen de primavera a primavera. Enrique comienza su viaje a través de las revoluciones, "en el día aquel, situándome en el comienzo de los Grandes Cambios (...) era una tarde de mayo" (p. 34); sale de la casa de su tía, Cuba, donde se está gestando un proceso revolucionario, en mayo de 1928: “-¿A quién carajo se le ocurrió esto de helar una piscina, en La Habana, en pleno mes de mayo? (p. 46); pasa por la primavera del 1943 -Segunda Guerra Mundial - en New York, pues “...le había subido a la cara esos colores de sangre activa que, en primavera, se pintan en las mejillas de quienes viven donde las estaciones del año se suceden con características marcadas, trayendo y volviendo a traer, en inevitable ciclo, sus ritmos, pulsaciones, floralias" (p. 293); y concluye su trayectoria en la primavera de 1961, durante la batalla de Playa Girón (p. 562).

Por su parte, la prima-Vera inicia su trayectoria en España durante la Guerra civil española (guerra que finaliza en la primavera de 1939), "donde puede repetirse un 3 de mayo" (p. 20); pasa por un 10 de marzo - Golpe de Estado de Batista-, "día que marcaba para mí el punto de partida de una serie de acontecimientos que nada parecía anunciar" (p. 320); y finaliza oyendo en Barbacoa, por radio, las palabras que Fidel Castro pronunció en el acto de sepelio de las víctimas del bombardeo del 16 de abril (p. 575). Igualmente, la trayectoria de Vera en el mundo de ficción parece estar articulado desde la Navidad de 1917, donde asiste al parto de Capitolina y al nacimiento de la Revolución rusa, hasta la Navidad de 1958 cuando Batista abandona Cuba y comienza la Revolución cubana.

Es evidente, entonces, que las revoluciones "a ras de suelo" se estructuran en el mundo narrado de La consagración de la primavera al ritmo cosmológico. Es decir, el curso de los personajes va de una revolución a otra en perfecta sincronía con el movimiento del cosmos de una primavera a otra; las revoluciones se articulan según el movimiento de los astros, de acuerdo a la traslación de la tierra. Así, la primavera, metáfora de la revolución, contribuye a la conformación de un mundo dialéctico, en constante movimiento y cambio.

Además de la primavera, el mundo narrado está elaborado de otro elemento de la naturaleza que también está en relación con el movimiento de los astros y que, por lo tanto, participa de la misma naturaleza dialéctica, repetitiva. Como los meses primaverales y las revoluciones manifiestan en su comportamiento el movimiento, así los días revelan la misma realidad: ... día $\longrightarrow$ penumbra $\longrightarrow$ noche $\longrightarrow$ amanecer $\longrightarrow$ día..., siguiendo el giro de la tierra sobre el eje. Cuando Vera sale del teatro donde asistió, en Valencia, a la representación de 
Mariana Pineda, narra: "y salimos del teatro, pasando de la luz amarillo-naranja (...) a las penumbras de pasillos que conducen a la noche demorada por la espera de un amanecer todavía lejano" (p. 25). Vera está en la "noche oscura" de España; espera ver en un día lejano el sol en su cenit. Por eso, Enrique distingue perfectamente "... un inconciliable desajuste entre el tiempo del Hombre y el tiempo de la Historia. Entre los cortos días de la vida y los largos, larguísimos años, del acontecer colectivo. Entre lo que se contempla hoy como realidad gestación, próxima al alumbramiento, y lo que verán los ojos como realidad todavía incumplida, retardada, modificada, aún por hacerse, al cabo de la muerte de seis, siete, ocho calendarios, de hojas arrancadas y botadas al cesto, con lunaciones, santoral y chascarrillos" (pp. 83-84).

El árbol, como símbolo y rito de renovación, es otro de los elementos naturales que conforman la novela.

Vera en sus viajes -éxodos, fugas ante clamores - conoce "la infinita repetición del pino y del abedul siempre semejante a sí mismo..." (p. 11), la repetición de la palmera (p. 172). Pero un día, a través de Enrique, llega a conocer el más imponente de los árboles: la Ceiba: "testigo impasible y enhiesto de diez, veinte, ciclones (...) eje cósmico del universo... Y pensaba que el guajiro cubano, al llamar "madre de todos los árboles" a la ceiba debía acaso a su ancestral sabiduría la noción de que con ello identificaba a la Mujer y el Arbol, alcanzando la esencia primordial de todas las religiones, donde Tierra y Madre - con cifras de tronco y retoño - son la ecuación significante de toda proliferación (...) Tellus Mater (...) Hay, aquí, un Arbol-centro-del-Mundo" (pp. 214-215).

El árbol representa el cosmos vivo, la vida que se regenera periódicamente sin cesar, la realidad que se crea sin agotarse jamás. $Y$ puesto que la vida es un equivalente de la inmortalidad, el árbolcosmos puede por este hecho convertirse en el "Arbol de la Vida". Además, como la vida es la traducción de la idea de la realidad absoluta, el árbol se transforma así en ella en símbolo de esta realidad, se constituye en "el eje cósmico del universo". De ahí que el árbol, al constituir el pilar, "axis mundi", expresa la realidad absoluta en el aspecto de norma, de punto fijo, sostén del cosmos.

Nótese cómo en el texto se identifica el árbol, símbolo de la vida, con la tierra y la madre. Como el árbol, la tierra es valorada porque tiene una capacidad infinita de dar fruto, porque produce for- mas vivas: es una matriz que pocrea incansablemente. Es decir, en ella siempre se reconoce el destino de la maternidad, el poder inagotable de la creación.

En síntesis, como en las revoluciones históricas, en los elementos naturales se observa el mismo proceso: la repetición.

\section{B. El mito}

Algunos críticos, al interpretar las obras de Carpentier, han afirmado que sus novelas se estructuran de acuerdo con una concepción mítica de la historia (21). Alguno - como Lev Ospovat - sostiene que a diferencia de Thomas Mann que pretende "humanizar" el mito, Carpentier se propone revolucionarlo acentuando el principio activo y rebelde oculto en él (22).

De los acontecimientos narrados en La consagración de la primavera no se puede deducir que la visión de mundo sea una concepción mítica de la historia. Sin embargo, su espacio novelesco está repleto de alusiones míticas: Serpientes emplumadas (p. 34), Euménides (p. 36), Orestíada (p. 38), Paraíso terrenal (p. 56), Becerro de Oro (p. 147)... Entonces podemos sospechar que, así como el espacio de la novela está estructurado por revoluciones y estaciones del año, sobre todo por la primavera, de la misma manera también por diferentes mitos.

Por el año 1933, los preparativos para la Segunda Guerra Mundial eran ya evidentes. El incendio de Reichstag hace suponer a Enrique que el mundo entra en una época de Apocalipsis: "Sin haber causado víctimas siquiera, ese incendio se acrecía en las mentes, cobrando la dimensión fatídica de una obertura de Apocalipsis. Era como si se nos hablara, en idioma de teas, de lo que pronto habría de suceder; del caballo rojo-fuego montado por quien arrojaría la paz fuera de la tierra, mandando que nos degolláramos los unos a los otros..." (p. 82). En el texto, la relación paradigmática revolución-mito es patente: los acontecimientos agoreros anteriores a la Segunda Guerra Mundial - como en el Apocalipsis - son concebidos por Enrique como signos de fin de historia, de final desastroso para la humanidad.

Durante el año 1936, Paul Robeson -durante la Guerra civil española - en sus "spirituals" canta y todavía cree en que la esperanza del mundo no se ha escapado de la caja pandórica, pues opina que este mundo del mal podría vencerse si blancos y negros se reunieran "para echar abajo las perece- 
deras torres de Babilonia (...) para edificar una Ciudad del Hombre, hecha a medida del hombre, por siempre librada de harto exigentes Demiurgos, nunca saciados de laudes, hosannas y rogativas" (p. 147). Nuevamente, la revolución y el mito se entrecruzan en el texto novelesco: las torres de Babilonia, los Demiurgos se relacionan paradigmáticamente con la Guerra civil española.

Durante la Segunda Guerra Mundial, Enrique asiste - como todo el mundo- al espectáculo de ver arder la catedral de San Pablo en Londres, con lo que le parece perdida toda posibilidad de esperanza pensando que fue roto el Sexto Sello del Apocalipsis (p. 263). Más tarde, la Revolución cubana mostrará la posibilidad de volver a un Génesis, a un Paraído perdido, Edad de Oro, en donde no se dé la "explotación del hombre por el hombre" (p. 575), ilusión del mundo a través de todas las épocas. Así, Apocalipsis-Guerra Mundial y Edad de Oro-Revolución cubana se relacionan en el texto paradigmáticamente. Nótese, además, cómo la revolución y el mito han pasado de un proceso de degradación a otro de mejoramiento, de un Apocalipsis a un Génesis. Esta estructura se repite en las obras de Carpentier, según Carlos Fuentes (23). Añade también que a la nueva Génesis, Edad de Oro, se llega a través de una revelación: la revolución. Igualmente, Octavio Paz cree que toda revolución tiende a establecer una Edad mítica. El eterno retorno es para él uno de los supuestos implícitos de casi toda teoría revolucionaria. Toda revolución pretende crear un mundo libre donde el hombre pueda expresarse de verdad. Pero el hombre sólo podrá realizarlo en una sociedad revolucionaria, pues siempre el hombre luchará por una época, una parte del mundo, un estado social que le permita realizarse y expresarse: una Edad de Oro (24).

Durante el proceso revolucionario en Cuba, Enrique, en Venezuela, ante la vista de Caracas, describe la ciudad, donde hombres y mujeres son "atraídos por el nuevo espejismo de El Dorado" (p. 443). Los venezolanos de La consagración de la primavera buscan el paraíso terrenal allí donde no existe: el petróleo, el dinero, el capitalismo no son una Edad de Oro, porque hay explotación del hombre por el hombre.

El mito de Sísifo (25) es sólo mencionado por Vera dentro de un paréntesis de su monólogo. Sin embargo, como las demás alusiones míticas, interviene en la novela como un elemento más en la serie de aspectos de naturaleza espiral: evoca la idea del eterno retorno, de la repetición; es, como la historia, de naturaleza dialéctica.

El personaje Vera es quien más refuerza los aspectos míticos: con sus viajes, éxodos, fugas, nos recuerda a Odiseo; en cuanto descubridora de fuerzas creadoras, como anunciadora de luz y libertad, se nos asimila a Prometeo; y con Sísifo, se pone en marcha, y es eterna e incansable luchadora.

Obsérvese cómo todos los mitos analizados, usados para la elaboración del espacio novelesco, se relacionan con el problema del tiempo, con la interpretacción de la historia. Son mitos de naturaleza repetitiva que presentan una estructura circular, donde se destruye lo viejo, y así se renueva el mundo al inaugurarse un nuevo ciclo temporal. Como la revolución, el mito-rito es un proceso que se lleva a cabo para que tenga lugar la renovatio mundi. Al principio o al fin de todo proceso revolucionario y mítico, tiene lugar una serie de "rituales" que se encaminan a la destrucción y renovación del mundo, en relación paradigmática con la historia que se estructura a través de procesos de estructuración y desestructuración de diversas formaciones socio-económicas. Por eso la función del mito dentro de la novela - símbolo de lo que realmente sucede en la historia - no es enunciar un acontecimiento que tuvo lugar "in illo tempore", hecho que se constituye en precedente ejemplar para todas las situaciones futuras, sino que, como afirma Beigbeder (26), interesa más como "alianza de contrarios, coincidencia oppositorum", conforme a su naturaleza dialéctica.

\section{El Amor}

El amor, relación erótica, es otro de los aspectos de la novela que conforma una metáfora de las diversas revoluciones. Siempre será un amor en movimiento jadeante, un amor de venganza social, nunca un movimiento transcendental.

En La consagración de la primavera hay una doble dialéctica en lo que se refiere a las relaciones eróticas: el amor se realiza entre diversas parejas $\mathrm{y}$ de diversas formas.

El amor Ada-Enrique, en relación sincrónica con la Segunda Guerra Mundial, es un amor de amantes, inevitable, dialéctico: “...me parecía que lo era ya; que ya lo había sido, que mañana era ayer; que el cercano marzo se llamaba enero. Una realidad, de pronto percibida, se me imponía en tales valores de futuro ya vivido que excluía todo razonamiento..." (p. 91): "A veces levantaba yo 
la sábana que mal la cubría para contemplarla largamente, con mirada que se detenía con ternura sobre todo lo que, en noche siempre nueva, siempre distinta a la anterior aunque se repitieran los mismos gestos..." (pp. 112-113). Otras veces, alcanzaba caracteres míticos: "Y fueron los tiempos del desorden (...) De repente habíamos caído en un mundo fuera del mundo (...) sin días fecha..." (p. 94). Pero sobre todo es sexual, material: “...donde lo que vale es el sentimos, luego somos, y no entendemos más razón, más filosofía, que la razón de la sinrazón de nuestras anatomías confundidas" ( $\mathrm{p}$. 95).

El amor Vera-Jean-Claude, realizado mientras suceden la Guerra Civil Española y la Revolución Cubana como recuerdo, participa de las mismas características: es dialéctico, mítico, sexual. Se realiza en un "tiempo que volvía a ser el de otros tiempos" (p. 132). "Aquella noche hicimos el amor tres veces (...) con agónico anhelo de detener el tiempo..." (p. 170). "...y supe de un amanacer en los brazos de un hombre (...) en una deleitosa derrota había hallado la mujer que en mí palpitaba..." (p. 505).

Vera-Enrique en sus relaciones eróticas, que tienen lugar durante la Guerra Civil Española, la Segunda Guerra Mundial y la Revolución Cubana, muestran, igualmente, características míticas y dialécticas; en cuanto a lo sexual, se da un vaivén entre el amor del plano de amantes al plano de cónyuges (p. 316). "Y aquella noche Vera y yo hicimos el amor de modo prodigioso (...) tan memorable que, años después, recuerda uno esa noche, entre mil noches, entre mil y una noches, como algo que acaso no haya de repetirse..." (p. 234). “...cuando, esa noche, nuestros cuerpos volvieron a encontrarse, hicimos el amor maravillosamente, tornando a hallar las pulsaciones y apetencias de los primeros días..." (pp. 380-381).

El amor Teresa-Enrique, que se realiza mientras suceden la Segunda Guerra Mundial y la Revolución Cubana, se sale del esquema dialéctico-míticosexual: "Y esa noche, y las noches siguientes, conocimos el amor del amor sin amor. El amor juego, el amor-diversión, el amor combinatorio de invenciones y antojos, sin entrega profunda, en distanciamiento..." (p. 282). Y ese mismo rito se vuelve a repetir entre ellos una noche cuando ambos estaban borrachos (pp. 535-536). Aquí, la faceta del amor es distinta. Teresa, prisionera de un mundo automatizado, se hace presa del aburrimiento y la rutina, que destruye toda posibilidad de sorpresa en la vida. Con la agravante de que el amor, que podría ser el refugio donde se compense aquella vida rutinaria y esterilizante, participa también de la monstruosa regimentación. Parecido sucede en el amor Olga-Laurent (p. 364), donde, al estar encerrados en un mundo de egoísmo, el amor no puede ser instrumento de cambio, de revolución: sólo de hastío y cansancio. El amor Irene-Enrique, aunque son características propias, sigue el mismo camino: "Ni ella estaba enamorada de mí, ni yo de ella. Pero juntos nos divertíamos mucho, sin engorros, imposiciones, reproches ni celos" ( $\mathrm{p}$. 516)

Esta relación erótica - sexual, mítica o dialéctica - se realiza igualmente en el mundo de lo literario. Cuando Vera llega a París, entre las obras que ese día se estrenan en el teatro está "una pieza de marido-mujer-amante, con cama a la vista... (p. 366). La relación que se realiza en el plano de los personajes, se repite en el mundo de las imágenes.

Finalmente, un amor especial: "Mirta y Calixto, enlazados, se besaban largamente, de labios confundidos, en un abrazo de nunca acabar" (p. 388). Con Mirta-Calixto se rompe la oposición blanconegro, y donde esperaríamos ver dos universos sexuales distintos (blancos y sus mujeres; negros, con las suyas), la red de sexualidad se rompe como se rompen las demás relaciones - económicas, políticas, ideológicas - entre los hombres, al pasar de una formación socio-económica a otra. Es curioso observar cómo es la mujer blanca la que quebranta los tabúes sociales en el plano de la sexualidad por la simple razón de ser una mujer en un universo masculino, contra cuyo imperialismo lucha. Esta licencia, la violación de la "prohibición", la coincidencia de los contrarios, no tiene otra intención que la disolución de un mundo y la restanración de otro, como en el mito y en la revolución.

Como la revolución, la primavera y el mito, el amor está unido en la novela por una sutil red de homonimia, fruto de positivas observaciones de la espiral, que expresa la idea de lo relativo, del devenir y, como la luna en el curso de las fases regulares, evoca la idea del eterno retorno, de la repetición.

En La consagración de la primavera, las relaciones del hombre y la mujer obedecen las leyes de la repetición, "semen virile", líquido que se regenera sin cesar, periocidad de las mestruaciones femeninas concordando con las fases de la luna. Y sólo tiene explicación en un contexto socio-histórico (capitalismo y socialismo) que las determina. 
En este contexto, la lucha de clases no puede separarse de la lucha de sexos, que se refleja no sólo en el plano erótico, sino sobre todo en el económico, político e ideológico.

\section{Ch. El número tres}

Los últimos aspectos analizados muestran una característica que aparece común: los cañonazos se oyen tres veces; el segundo aire se siente en tres ocasiones.

Además, el número tres aparece, en cuanto número, en dos diferentes ocasiones: como elemento estructural de los ensayos de ballet y como ritmo

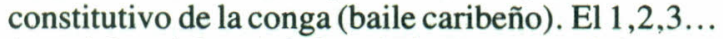
1yyyý 2 yyý $3 \ldots 1,2.3 \ldots$ de los ensayos de barras, es homologado por Mirta con el ritmo de la conga: " 1 y 2 y $3 \ldots$ ¡qué paso más chévere! / ¡qué paso más chévere / el de mi conga es!” (p. 576).

Si el número tres es elemento constituyente de los aspectos musicales de la conga, también se amplía a la estructura de la frase. Aquí los ejemplos son infinitos. Sólo vamos a observar una muestra que nos haga comprender la importancia del número tres en la repetición de las palabras:

"Todo eso me resultaba lejano, lejano, terriblemente lejano, y, sin embargo, cercano, cercano, tremendamente cercano..." (p. 273).

"Y bailar, bailar, bailar siempre" (p. 487).

"He nacido para danzar, danzar y danzar" (p. 482).

"Y ahora sí, y ahora sí, y ahora sí, que pasaremos las próximas pascuas en Moscú, en Moscú, en Moscú, oscú, oscú, cúuuuuuи, си́иииии, сииииии..." (p. 488).

"Porque aquello es el caos, el caos, el caos..." (p. 492).

“...aplaude, aplaude, aplaude interminablemente” (p. 280).

Si se observa el último ejemplo, se ve que la repeticióńn de palabras es sólo para mostrar que los elementos se pueden repetir "interminablemente". Con ello, el lenguaje entra en la misma relación de repetición que la revolución, el amor, la naturaleza... conformando un texto novelesco elaborado de contextos en movimiento.

\section{Las canciones:}

Las diferentes canciones que entonan los personajes a través de la novela, participan de características comunes: su contenido es revolucionario, son impresionantes y llegan con carga de emoción colectiva, comenta Vera (p. 155).

Los "espirituales negros" que canta Daul Robeson durante la Guerra Civil Española, --Show-boat, Heaven bound soldier - (pp. 145-146), nos trasladan a las riberas del Mississippi, en campos de algodón, donde un día esclavos negros elevaron el grito de su angustia, y el canto era el único medio de luchar por su libertad.

El mismo día en Benecassim "Unas voces muy lejanas que, nacidas a distancia calculada, para lograr el efecto, se alzan, coralmente, pianísimo, como si estuvieran muy lejos (...) Y esas voces, con un himno lento, apoyado en las notas tenidas (...) se acercan, se levantan, crecen, en palabras": "Freiheit" ("libertad", traduce el cubano) (pp. 148149).

Las carmañolas, los partisans, Los Cuatro Muleros, El vito del Quinto Regimiento, el Anda, jaleo, jaleo, con versiones especiales de letras, saltan por encima de los años, de las décadas, y enlazan acontecimientos distantes y distintos: La Comuna de París, el 17 de Octubre en Rusia, la Guerra Civil Española (cpp. 151-152)

Más tarde, durante la Revolución Cubana, Gaspar y Enrique vuelven a entonar la tonada de $L o s$ cuatro muleros y El vito del Quinto Regimiento (p. 387).

Sin embargo, entre todos estos himnos y canciones, se destaca La internacional, con música de Degeyter y letra de Eugene Pottier. En España, se escucha en diferentes lenguas - alemán, italiano, francés, español (pp. 153-154):

\footnotetext{
“AArriba, parias de la tierra!

¡En pie, famélica legión!

Los proletarios gritan: ¡Guerra!

Guerra hasta el fin de la opresión.

¡Borrad el rostro del pasado!

¡Arriba esclavos, todos en pie!

El mundo va a cambiar de base,

Los nada de hoy todo han de ser.

Es la lucha final

Juntos todos cantemos:

La Internacional

Será la Humanidad" (p. 154).
}

Estas notas se habían escuchado ya en Rusia durante la revolución, aunque con diferente tono. El narrador, por eso, da una nueva traducción:

"De pie los pobres de la tierra,

De pie los hombres sin pan (p. 175).

Del pasado hagamos tabla rasa,

De pie, esclavos, de pie:

El mundo va a cambiar de base,

¡no éramos nada, seamos todo”... (p. 177). 
Sacha advierte el sentido político y revolucionario del himno: "Esto que es, en Francia, un himno nacional, se ha vuelto aquí una llamada a la insurrección armada" (p. 178).

Por fin, después de oírse La internacional en Francia, en Rusia, en España, en el mundo entero durante la Segunda Guerra Mundial, se oye un día en U.S.A. en un cabaret (pp. 279-280).

En la Revolución Cubana, los himnos participan de las mismas características. Las manifestaciones populares durante la Segunda Guerra Mundial, cantan tonadas conocidas con letras "tintas de chunga criolla":

"El Comunismo

es la libertad.

Cógete a Polonia

y dame la mitad" (p. 235).

En resumen, el mundo narrado está elaborado también por un contexto musical de carácter popular y revolucionario en relación paradigmática con la historia de las revoluciones. Y así como entre ellas, debido a la ley de la concatenación universal de los fenómenos, se observa una interdependencia, de la misma manera las canciones unen espacios y acontecimientos distantes y distintos, contribuyendo a la elaboración de un cosmos dialéctico.

\section{E. El agua}

El agua es otro de los componentes del espacio novelesco que entra, en relación metafórica con las revoluciones, a formar parte de la suma de aspectos con los que se elabora la novela. En La consagración de la primavera, el agua aparece en tres de sus manifestaciones: como mar, como lluvia y como nube.

El mar de España que observa Vera es "uno y múltiple, varón y hembra (...) camino de naves que por el grado de las arboladuras pregonaban el siglo a que pertenecían -imagen efímera del tiempo humano para el agua sin tiempo que en este litoral depositaba sus algas y medusas desde los Siete Días que Conmovieron el Cosmos” (p. 125). Este mar mítico sin tiempo se opone a otro mar "toujours recommencée", en constante movimiento, opuesto a la quietud, y "a la majestuosa fijación de la montaña" (p. 13). Este mar mediterráneo recuerda a Vera otros mares conocidos desde su infancia “...desde la cuna - aunque el mar de allá era acaso más obscuro, más lento en sus desperezos, más tardío en alisar las playas, en hacer rodar guijarros con ruido de granizo apretado" (p. 13).
Esa misma sensación de vuelta a la infancia reciben Vera y Enrique en el mar Caribe: “...y después de un largo baño en el agua de un mar que me olía y sabía realmente a mar, porque era el mar de mi infancia". (p. 536).

De la misma manera que Vera tuvo fugas, éxodos a raíz de las revoluciones, así el mar, uno y múltiple, la lleva a cada ciudad conocida, vivida, sentida en función de mar; y cada ciudad habrá de ejercer sobre ella una atracción a la vez una y múltiple (p. 466). Por eso, cuando llega a Barbacoa, la última playa de la historia, llega a la conclusión de que: “...es el mar en todas partes, el mar siempre próximo y metido en el olfato..." (p. 455).

La lluvia, además de mostrarse en forma de sueño (p. 48) aparece como fuerza, destrucción.

El deshielo que se produjo en la piscina de la casa de La Condesa, ocasionó el desastre, un verdadero cuadro de ruinas. Para Enrique aquel cuadro lúgubre, fatídicamente agorero, se le hizo visión de teatro en quiebra (p. 50).. (Todo aquel entarimado político se vino abajo años después con la Revolución Cubana).

Otras veces, la lluvia aparece relacionada con alguna forma de creación. Vera la siente así el día que conoce a Anna Paulova en Londres después de que esta ha acabado su representación artística en el teatro, y aquella le solicita una zapatilla que le acompañará en todos sus viajes (p. 143).

Las nubes cubanas se muestran en la novela como son en el trópico: "Antojadizas y volubles (...) las Señoras de Arriba, prometedoras de Grandes Lluvias (...) Anárquicas en la perpetua mutación de colores" (pp. 208-210).

En resumen, el espacio de la novela está elaborado de elementos relacionados con el agua que sugieren la repetición en contradicción con los que postulan lo estático: mar vs. montaña; lluvia destructora vs lluvia creadora; nubes destructoras vs nubes inocentes. Esta lucha de elementos heterogéneos, como la lucha de clases sociales en las revoluciones, se constituye en fuente de progreso, fuerza motriz del mundo narrado.

El agua -como las plantas (árbol), la mujer (Mater), la tierra (Tellus) - está unida por una red de homonimia con la espiral, la cual expresa el devenir, la idea del eterno retorno, la repetición. El agua es un factor esencial del renacer y de la fertilidad, y el mar evoca el dominio de la perfecta indistinción, así como la virtualidad y el devenir, con sus olas y ondulaciones que se reproducen sin cesar. 


\section{F. La música (Vera)}

Así como la Historia es, por esencia, dinámica, dialéctica, y como Enrique se constituye en símbolo de ese dinamismo, de la misma manera Vera sufre un proceso: la artista apolítica se convierte en la artista revolucionaria; por otra parte, la Danza, el ballet (Vera), en relación paradigmática con las revoluciones, se elabora en el texto, conformando una metáfora de la revolución.

Vera, nacida en el 1909 (p. 420), y criada en Bakú y Petrogrado en la época de la Revolución Rusa, se refugia en el ballet, cerrando los ojos a la realidad política que vive, porque las revoluciones no le han causado más que separaciones de su hogar, patria y seres queridos. Al llegar a París, busca una iglesia en donde solucionar sus problemas; sin embargo, no lo logra, pues su religión se rige por los cánones burgueses, es decir, idealistas (pp. 198-199). Por eso, será su vocación de bailarina la que, como siempre, distraiga a Vera de sus preocupaciones políticas. Su vida se desarrolla siempre "a ras de suelo (...) soñando con los Grandes Cisnes Negros" (p. 11), atenta al metrónomo, al ritmo machacón y falso del pianista de ensayos (p. 51). Y cuando llegan las revoluciones, vuelve una y otra vez el ballet (p. 181). La Danza se constituye, así, en la razón de ser de su existencia (p. 202).

En la conformación de esta vocación, tuvo que ver Anna Paulova "Espirítu de la Danza que se hizo carne y habitó entre nosotros” (p. 140). La zapatilla y el retrato que le regaló es el espíritu, el talisman (p. 143) que va conformando el cambio que se opera en Vera cada vez que los contempla (p. 413). Hasta a Baracoa los lleva (p. 487), y cuando la Revolución Cubana ya está en proceso de maduración, Vera coloca el talismán en la vitrina de su cuarto (p. 576), para que la guíe en la nueva versión de La consagración que va a comenzar a realizar.

El proceso de politización de Vera comienza en 1953, cuando quedan frustrados sus planes de presentar su ballet en New York, al negársele la visa por razones políticas. Ella misma se percata del cambio: “¿Yo, la apolítica, politizada?” (p. 377).

Sin embargo, la verdadera conversión se realiza cuando Vera descubre los cadáveres de tres de los integrantes de su Compañía a manos de los militares de Batista, y al percatarse de que su marido le ha sido infiel con su prima Teresa.
La resurrección se efectúa en Baracoa. El médico, cual guía sabio, la orienta en la Historia y la Literatura de Cuba. Al mismo tiempo, ella va identificándose cada día más son Fidel Castro y los revolucionarios de Sierra Maestra, entre los que se encuentra su "hijo" Calixto. La victoria definitiva de la Revolución coincide con la revelación de Vera:

"He querido ignorar que vivía en un siglo de cambios profundos y, por no admitir esa verdad, estoy desnuda, desamparada, inerme, ante una Historia que es la de mi época -época que quise ignorar" (p. 509).

De esta manera, Vera apolítica, burguesa, había pasado a Vera política. Cuando se dirigía a España, su vida estaba pasando por "una noche de tinieblas" (p. 11), aunque se vislumbraba un paisaje de albas. Las revoluciones la habían traumatizado (p. 283). Poco a poco, se va desarrollando en ella una transformación (p. 371). Presiente la imposibilidad de escapar, "me esfuerzo en zafarme de lo vivido, en borrar mis propias huellas, en olvidar los caminos recorridos. Pero esos caminos me siguen los pasos" (p. 473). Sierra Maestra la va acercando, hasta que se entrega a la Revolución, puño en alto (p. 510).

La educación burguesa que había recibido desde su niñez fue uno de los factores responsables de su traumatización. Le habían enseñado a bailar, a portarse bien en las recepciones, a servir el té, a hacer reverencias a las personas nobles, a conocer la gramática, matemáticas, Historia Sagrada e Historia Patria, esta última en función de coronaciones, triunfos y evangelizaciones; a estudiar un poco de lengua eslava, inglés; saber honrar a padres, adornar una mesa, ayudar a las madres en los quehaceres domésticos; a no ignorar las artes del bordado, del dibujo de flores, la técnica del pirograbado, solfeo, piano (p. 465). En resumen, educada para ser una muchacha "decente". De ahí que el proceso de cambio fue lento, largo y penoso, como el de las revoluciones históricas.

La Danza, desde el título de la novela, se constituye en un elemento significante.

La vida de Vera ha sido siempre, desde la niñez a la madurez, desde el inicio de la obra hasta la última página, "a ras del suelo. Hasta ahora sólo he vivido a ras del suelo, mirando al suelo $-1 \ldots$ $2 \ldots 3 \ldots$... (p. 11). Toda su vida se ha caracterizado por el impulso, la rotación, el girar sobre sí misma, la danza, "regresos a efímeras inmovilidades de estatua que busca la inmovilidad de la estatua en el inseguro equilibrio" (p. 11), en el estudio de la 
Academia. Desde el primer día que entra al ballet de Madame Cristine en Petrogrado, su vida se caracterizó por "bailar, bailar, bailar siempre" (p. 478).

Después de pasar por las Academias de Petrogrado, Londres, París, retorna al ballet al llegar a Cuba. Abre una Escuela en Vedado, donde se van relevando diversas generaciones de alumnas (p. 297). La Academia progresa, se ensancha, y abre una nueva Escuela en La Habana vieja. La Escuela sigue caminando, entran nuevas alumnas, otras se van. Sin embargo, realizan progresos prodigiosos por inspiración natural (p. 354). Además, gracias a los medios económicos que le proporcionaba la Academia de la burgués Vedado, podía educar a los de La Habana vieja. Así, los dineros de la burguesía comenzaban a servir para el pueblo (p. 380).

Así comenzaba a sentirse en Cuba el "Espíritu de la Danza”. Y aquello que comenzó con salidas de alumnas mayores y entradas de jóvenes, acabó "consagrándose" en el Ballet Nacional de Cuba, dirigido por Alicia Alonso, donde hoy danzan $\mathrm{Ca}$ lixto y Mirta (p. 538). La primavera había iniciado una nueva consagración.

Aunque La consagración de la primavera, de Stravinsky, es la obra con la que se conforma la novela, sin embargo, existen otras piezas musicales con las que el narrador también elabora la obra, usadas para subrayar y ampliar las dimensiones significativas de la novela: el Carnaval, de Shumann, parodia que presenta el relato, y la Obertura 1812, de Tchaikowsky, que sirve para el ciclo de las revoluciones del siglo XX (27).

Aunque pareciera que en ningún momento se concretan en sus representaciones las piezas musicales que se ensayan, sin embargo, es todo lo contrario: las funciones de las danzas se cumplen en

las revoluciones de turno. Así, la preparación de la Obertura 1812, en Petrogrado, se logra con la Revolución rusa (p. 482 ss); la primera preparación de La consagración de la primavera, en París, con la Segunda Guerra Mundial (p. 186); y cuando Vera intenta llevar a escena, en Cuba, La consagración de la primavera, se repite el mismo fenómeno: se cumple en la Revolución cubana.

El engranaje entre la danza y la revolución vuelve en la elaboración del mundo narrado cuando el narrador, en marcado contrapunto, presenta los acontecimientos principales de la Segunda Guerra Mundial al mismo tiempo que la Academia de Vera en Cuba alcanza cierto progreso: Salermo, Normandía, liberación de París, muerte de Roosevelt, Hiroshima... acontecen mientras la Academia progresa en barras, barras y más barras, piruetas y más piruetas (pp. 297-301). En Cuba, la "Danza Macabra" se registra en manifestaciones públicas (p. 235), en titulares en los periódicos (p. 234), y en la amenaza de los submarinos alemanes frente a las costas cubanas (p. 263). Paralelamente a la Segunda Guerra Mundial, Vera fracasa como bailarina y se convierte en maestra de danza. Y aunque piensa en La consagración de la primavera, prepara con sus alumnas el Carnaval, de Shumann (p. 245).

El Carnaval se traspasa a la guerra. Al llegar Enrique a New York, la ciudad baila al ritmo de "Danza Macabra", mientras que en Stalingrado se libra la verdadera batalla y los norteamericanos entonan música rusa (p. 269) y bailan La Internacional. Mientras tanto, Vera concluye la representación del Carnaval, en Cuba, con triunfo artístico.

Pero el engranaje entre las dos imágenes es más perfecto cuando la Danza comienza a bailarse en Cuba con artistas autóctonos. El día 10 de marzo de 1952, Batista se ve obligado "a hacer una revolución (...) porque tenía noticias de las fuentes más dignas de crédito, de que el Presidente Prío, enfrentado a la derrota de su candidato en las elecciones del primero de junio, estaba preparando una revolución espúrea para el quince de abril" (p. 319). Cuba queda así incorporada al ballet de la "Danza Macabra". Mientras tanto Vera, al realizar estudios para la representación de La consagración de la primavera, descubre sobre una partitura de la pieza "que el Cortejo del Sabio (o Augur) aparecía, acaso añadida a la instrumentación primera, una parte de guiro cubano, con precisa indicación del uso de la varilla rascadora tal como la movían, hacia arriba o hacia abajo, los músicos de acá" (p. 330). Así vuelve a reforzarse el vínculo entre danza y revolución.

Del mismo modo se puede cotejar vínculo entre las dos imágenes cuando los ensayos de La consagración de la primavera van progresando y su triunfo inicial se relaciona con el triunfo de la llegada a feliz término de la compañía revolucionaria.

La propia Vera establece la relación cuando afirma que "mi compañía - pues ya podía llamarla asífuncionaba como un mecanismo de relojería" (p. 412 ), pronunciamiento que ya había hecho al referirse al funcionamiento de los grupos revolucionarios: "Aquello había funcionado como un mecanismo de relojería" (p. 397). 
Finalmente, la fuga de Vera hacia Baracoa es fiel copia del refugio al que se acoge el líder revolucionario en las montañas de Oriente.

En resumen, danza y revolución se estructura paradigmáticamente en la novela, conformando la música una verdadera metáfora de la revolución.

\section{G. Movimientos artísticos e ideológicos}

El análisis que estamos realizando permite enfrentarnos a un fenómeno bifronte que manifiesta, por una parte, una realidad histórica y, por otra, el redoble simbólico de esta realidad. Sin embargo, de los elementos hasta ahora analizados con esta característica, ninguno alcanza tanta importancia como el poder revolucionario del arte. Con razón Mario Benedetti, al establecer una dialéctica entre revolución y arte, no se asombra de que la Revolución Cubana haya seguido un proceso afín con el de una obra de arte (28). Nosotros vamos a mostrar aquí cómo los movimientos artísticos e ideológicos - cine, pintura, música, literatura, filosofía - en la novela, siguen un proceso paradigmático al de las revoluciones del siglo XX.

Los personajes de la novela se enteran, por las carteleras que las anuncian, de las películas de Cecil B. de Mille (p. 42), Chaplin (p. 204), Fritz Lang (p. 94), Luis Buñuel (pp. 75, 235, 268); evocan las películas de Hollywood sobre la Segunda Guerra Mundial y la Revolución Rusa: El acorazado Potenkine, Octubre, Tchapaieff, La línea general (p. 269).

En pintura, las novedades del siglo XX repercuten en la vida de los personajes de la ficción: el realismo de principios de siglo de Zuloaga, Sorolla, Zubiaurre, Romero de Torres, Muñoz Degráin (pp. $52,54.218,225,231,332)$ : picadores y toreros, pescadores mediterráneos, andaluzas, remeros vascos, después superados por los diversos movimientos de vanguardia que profesan nuevas concepciones sobre la creación artística. Un verdadero vendaval parece pasar por los terrenos de la pintura, como por los de las demás manifestaciones artísticas.

El impresionismo de Pablo Cezanne repercute en las ideas estéticas de Enrique durante la dictadura de Machado, a través del cuadro "El cesto de manzanas" (pp. 56, 214, 371). El cubismo de Pablo Picasso rompe la estética anterior, y cala en el espíritu de Enrique, aunque no lo entiende:

"Líneas, manchas, superficies planas, formas sueltas o imbricadas, pedazos de papel, de tela, pegados sobre entrecruzamientos de trazos que eran como rejas de asimétricos barrotes; a veces, alguna remota alusión plástica a una fruta, una botella, un instrumento musical; a veces un asomo de cara, difuminada, torcida, como hincada de cuñas - todo desprovisto de significado, de asunto, y peor aún cuando se alcanzaba a la geometría ascética y huera, superficie sin contenido ni discurso, de un indignante "artista" que fabricaba sus "obras" a regla, escuadra y cartabón, encerrando, entre rayas negras, unos rectángulos de color tan uniformes y planos que parecían conseguidos con pintura destinada a usos industriales..." (p.. 53).

Esta técnica crea los fruteros de Pablo Picasso, Juan Gris y Jorge Braque (p. 56). Quienes la siguen son considerados avanzados (p. 84). Desde entonces, "Guernica" se considera la muestra más evidente de Los horrores de la guerra (p. 98, 128, $168,332,411)$.

Enrique observa trabajar en su taller a Diego Rivera, en México, amigo de Picasso, de Braque y Gris, pero que, según Enrique, se apartó de su cubismo para "dar forma - de poner en formasel espíritu de un gran acontecimiento histórico que había devuelto al Indio algo de su personalidad perdida en la colisión de dos mundos..." (pp. 6465). Así Diego Rivera se encauza hacia una pintura figurativa, narrativa, furiosamente significante, al contacto de la tierra americana.

A través de conversaciones, visitas a museos, Enrique se acerca a otro movimiento de vanguardia que va a tener posterior desarrollo en la literatura: el surrealismo de Juan Miró (pp. 168, 353, 448). Renoir le lleva hacia el impresionismo (pp. 353, 411), lo mismo que Matisse (p. 353) y Raúl Dufy. Pablo Klee le introduce en el arte no figurativo (pp. 353, 411).

Los personajes del mundo narrado, además del cuadro de pintores de los movimientos de vanguardia, comentan de pasada sobre dos pintores españoles que se distinguieron por ser verdaderos revolucionarios en el arte: Francisco Goya y El Greco (pp. 182, 206, 323). De esta manera, se ven invadidos por el mundo de la pintura del siglo XX, con sus autores más representativos y los movimientos a que pertenecen; y así se instalan en el contexto histórico pictórico que, como los demás contextos, repercute dinámicamente en su vida.

La música es otra de las artes que conforman el contexto artístico de la novela. Como en la pintura, los narradores aluden, citan, oyen, comentan sobre autores y movimientos más representativos en el campo musical.

Igor Stravinsky es sin duda alguna el músico más mencionado por los narradores. Además de La consagración de la primavera, mencionan otras 
obras: Las bodas (p. 243), El pájaro de fuego (pp. 337, 391), Petrouchka (p. 391) y Oedipus (p. 367). Excepto la última obra, las demás son de ballet. La razón de la incorporación al texto de estas obras reside en que, además de conformar el contexto musical de la época, están construidas con una técnica de naturaleza dialéctica en relación paradigmática con la Historia: grandes bloques de sonidos y patrones sonoros, a menudo basados en "ostinati", colocados unos contra otros en ciclos repetitivos y alternates que, aunque aseverativos y de naturaleza inflexible, ganan vitalidad y hasta sentido de movimiento al ser constantemente reinterpretados en cambiantes superposiciones de acento, ritmo, metro y frase. Es decir, la música de Stravinsky es un símbolo, en la novela, de la naturaleza dialéctica de la historia. Su carácter repetitivo, siempre idéntico y siempre distinto, es homólogo al de las revoluciones históricas.

Prokofiev es mencionado por los narradores formando un solo conjunto con Stravinsky, Diaghiley y Balanchine (pp. 67, 160, 183, 311). Los dos últimos, aunque no son creadores musicales, son el director del ballet y el coreógrafo que dieron vida a las obras. Ambos elementos - dirección y coreografía - son elementos dinámicos, metáforas de la revolución.

Tchaikosky es otro de los músicos aludidos por los personajes en la novela. Sus obras "Obertura 1812”, Quinta Sinfonía, El Cascanueces, La bella durmiente llenan la obra de una atmósfera de ritmo, movimiento, de ballet.

Balakirev, Glinka, César Cui, Schostakovicht completan la lista de la música rusa que escuchan los personajes al finalizar la Segunda Guerra Mundial. La función de su inserción en el texto es patente: conformar, en relación paradigmática con los hechos históricos, el contexto musical de la época. Alrededor de la Revolución Rusa y la Segunda Guerra Mundial, el mundo del siglo XX bailó y cantó al son de la música rusa.

Los narradores aluden a músicos rusos representativos del ballet y de temas regionales o nacionales.

Respecto a la música española, vuelven a inclinarse por los mismos cánones, sobre todo, por lo nacional: Tomás Bretón (p. 152), Amadeo Vives (p. 26), Granados, Falla, Albéniz y Casals son los músicos sobre los que comentan los personajes de la novela. Su función es homóloga a la de los rusos: por un lado, se comenta sobre ellos en relación paradigmática con la Guerra Civil Española; por otro, a la gran importancia de la música española en el contexto musical del siglo XX. A mediados de siglo, el mundo estuvo pendiente de la Guerra Civil Española y bailó al son del pasodoble español.

El narrador incorpora todos los movimientos modernos del siglo XX en cuanto a música se refiere. Todos ellos, aún los que se suele describir como "conservadores" han participado de la búsqueda de nuevas formas. Las viejas formas, las viejas estructuras expresivas, pueden ser englobadas por la frase "tonalidad funcional". Pero desde 1900, los viejos postulados cesaron de funcionar como supuestos "a priori", y el arte moderno tuvo que establecer sus propias premisas expresivas.

Como la Revolución Cubana sólo tiene explicación por la interacción de acontecimientos, así la música del siglo XX sólo se puede comprender si miramos al pasado. Beethoven (pp. 54, 143, 272, 288 , 326), Bach (pp. 105, 343, 459) y Wagner (pp. 95, 277, 344) siguen siendo decisivos en la formación de ideas y técnicas del siglo XX. La libertad modulatoria de la música de Bach está en relación directa con la libertad cromática e incipiente "atonalidad" de Tristán e Isolda de Wagner y, a su vez, su técnica contrapuntística puede ser percibida después en la música de compositores como Mahler. La concatenación se da no sólo entre hechos históricos sino también entre movimientos artísticos. Por eso, pasado y presente, en cierto modo, están unidos. Beethoven, Bach, Shumann, Mozart, Schubert... influyen en el presente y su influjo no se puede olvidar.

Esta concatenación de los postulados musicales desemboca en el siglo XX, como las diferentes revoluciones históricas en la Revolución Cubana, en una serie de movimientos musicales revolucionarios que los personajes comentan y que de alguna manera influyen en sus vidas: el impresionismo, el surrealismo, la neotonalidad, la politonalidad, el dodecafonismo, la música no lineal: tonalidades simultáneas y diferentes, agrupamiento de ritmos repetidos, grupos de notas que se repiten una y otra vez en formas rítmicas distintas, conforman el contexto musical de una época dialéctica caracterizada por el movimiento y el cambio. Mahler (p. 493), Milhaud (pp. 185, 244), Hindemith (p. 185), Schonberg (p. 493), Varese (pp. 349, 382, 412, 413)... son los responsables de ello.

En resumen, el mundo actual no sólo se mueve a ritmo de revoluciones. El contexto musical de la época hace de la novela - como de la historia- la época más dialéctica que han contemplado los siglos. 
En el siglo XX, se han dado grandes transformaciones sociales e ideológicas; la evolución en el plano científico no ha sido menor, así como en el filosófico.

Todo ello encuentra un notable paralelismo en las profundas transformaciones que se operan en las artes durante el siglo XX. En todos los terrenos, junto a pervivencias de estética anterior, surgen movimientos que rompen violentamente con los presupuestos artísticos vigentes hasta entonces. Los científicos, los artistas, los filósofos, desechan nociones y enfoques antes sólidamente establecidos.

Respecto al contexto literario, desde principic de siglo se han experimentado sucesivas mutaciones. Estos cambios, debido a la concatenación de los fenómenos, tienen relación con fenómenos literarios anteriores. El camino, como en las revoluciones, ha sido largo: el mundo clásico: Homero (p. 343, 344), Boccacio (p. 97), Shakespeare (pp. 101, 131), Dante (p. 101), Petrarca (p. 101), Virgilio (p. 344), Sófocles (p. 120); la literatura del siglo XIX: romanticismo, realismo, naturalismo: Novalis (p. 15), Víctor Hugo (pp. 299, 131, 471), Pushkin (pp. 275, 471, 485, 504), Walter Scott (p. 474), Goethe (pp. 102, 164, 106), Schiller (p. 106), Stendhal (p. 138), Ibsen (p. 368), Galdós (pp. 138, 332), Dostoyevsky (pp. 176, 367, 432, 504), Chejov (pp. 367, 504), Flaubert (p. 471), Gogol (p. 504), Zola (pp. 138, 471), Dreisser (p. 165) ...influyen poderosamente en el contexto del siglo actual, de la misma manera que las revoluciones en la Revolución Cubana.

Así van apareciendo los diferentes movimientos de vanguardia de los que van tomando noticia los diversos personajes de la novela: cubismo, dadaísmo, creacionismo, surrealismo. Estos movimientos producen verdaderas "rupturas" con los movimientos anteriores; muchos de ellos escriben en Manifiestos sus nuevas ideas sobre el arte y las letras. Enrique, Vera, Gaspar, José Antonio... nos introducen en el contexto literario de la época: a través del comentario de un libro, de la crítica de una novela, de la opinión de una obra de teatro, de la lectura de el mundo narrado está conformado por Federico García Lorca (pp. 24, 200, 283, 285), Vicente Huidobro (p. 81), Tristan Tzara (p. 81), André Bretón (pp. 81, 30, 230, 254, 267, 273, 274), Aragón (pp. 83, 167), César Vallejo (p. 98), Alfred Jarry, Rafael Alberti (p. 161), Miguel Hernández (pp. 161, 200, 242), Vicente Aleixandre (p. 161), León Felipe (p. 161), Emilio Prados (p. 163), Hemingway (pp. 161, 163, 202, 229, 353,
361), Unamuno (p. 227), Marcel Proust (p. 56), James Joyce (pp. 230, 344), Ortega y Gasset (pp. 230, 369), Henry Miller (p. 269), Melville (p. 356), Bertolt Brecht (p. 524), Laurence (p. 224) Anatole France (p. 223), André Gide (p. 332), Malraux (p. 128), Antoin Artaud (p. 192)...

La función de la inserción del contexto literario en la novela es homóloga a la de los demás movimientos literarios: conforman un cosmos total, presentar al hombre dentro de unas circunstancias precisas y determinadas, reflejar la vida del ser humano en una época determinada, tal cual debido precisamente a esas circunstancias.

Igualmente, los narradores incorporan a la novela representantes de movimientos de carácter filosófico que se desarrollan desde principio de siglo: Nietzsche, Bergson, Heidegger, Freud, Marx, Lenin, Engels. Además, citan o comentan sobre otros movimientos de menor importancia: el neotomismo de Maritain (p. 201), el revisionismo (pp. 75-78, el neotomismo de Maritain (p. 201), el revisionismo (pp. 75-78), el mecanismo (pp. 160-161), el anarquismo (pp. 26-27). Los narradores incorporan al mundo narrado los cambios operados en los movimientos ideológicos con sus representantes más importantes. Todo ello con el objeto de completar el cuadro de la época desde el punto de vista de la filosofía.

En La consagración de la primavera, el contexto arquitectónico es persistente como marco del acontecer humano, pues en ella concurren como elementos contextuales todos los movimientos de vanguardia artística con el objeto de mostrar una realidad cambiante, variable, en constante transformación, dialéctica, y así vincular al hombre con su entorno en un nuevo universo de formas, surgido de las transformaciones dialécticas que se producen en la sociedad.

Los protagonistas de esta novela surgen de la ciudad y van pasando de una ciudad a otra en relación metafórica con las diversas revoluciones que allí se están gestando en ese instante. Vera pasa por Bakú, Petrogrado, París, Madrid, La Habana; Enrique, por La Habana, México, París, Madrid, La Habana. Los protagonistas van tejiendo sus recuerdos sobre ciudades lejanas (ayer cercanas); de esta manera, las ciudades acompañan al ser humano en su diario vivir. Desde luego que, como las revoluciones del siglo XX con características propias cada una de ellas, así las ciudades poseen su propia personalidad acorde con las funciones que allí se realizan: Madrid, reflejo de la crueldad humana de 
las fuerzas reaccionarias; París, como Ciudad-delos-Balcones-Desiertos (p. 68); La Habana, colonial y proletaria. En todas ellas, unas veces su imagen es estática; otras, dinámica, constatando las contradicciones de la vida social que en ellas se contiene.

En resumen, si ha habido alguna época dialéctica en la historia de la humanidad ha sido el siglo XX: en nuestros días, los movimientos artísticos e ideológicos aparecen y desaparecen casi simultáneamente. En siglos anteriores, duraba siglos la trayectoria de su nacimiento, desarrollo y desaparición; hoy, en unos años, nacen, viven y mueren.

No queremos acabar este apartado sin responder a una pregunta ¿Es La consagración de la primavera sólo política? ¿Dónde están las obras artísticas de la Revolución Cubana? En el texto no aparecen. Con la Revolución política se establecen las premisas para la aparición de una nueva sociedad. Habrá que cambiar, primeramente, toda la estructura económica. Por eso, el arte se queda atrasado en relación con el desarrollo político y económico, y se mueve, en parte, dentro de los viejos cánones recibidos. Encontrar nuevas formas y contenidos artísticos tardará varios años.

\section{H. El mito la consagración de la primavera}

La consagración de la primavera, título de la novela, es un mito ruso que Stravinsky reinterpreta musicalmente en un ballet.

En sentido literal, el título de la novela se refiere a esa composición musical de Strasvinsky, que estalló como una bomba revolucionaria en 1913. En el plano metafórico, primavera se refiere a la Revolución cubana. Consagración, como se dijo, implica mitificación, afirmación sagrada, culminación de una serie de revoluciones que comenzaron en 1789.

Nada más abrir la novela, Vera, cuando se dirige a España, reinterpreta el mito de la primavera, relacionándolo con la Epopeya de los Nartas que le contaba el jardinero de su padre cuando ella era una niña:

“...cuando los hombres del Caballo y de la Rueda, cansados de errancias de sol a sol, de luna a luna, en praderas de nunca acabar, vieron erguirse una cordillera enorme, al cabo de un andar de muchos años entre horizontes idénticos, del solsticio del trébol al solsticio del cierzo - y vuelta al trébol y vuelta al cierzo-, prorrumpieron en sollozos y se prosternaron, atónitos y maravillados, ante lo que sólo podía ser morada de los Amos de todo lo Visible y lo Invisible, creadores del Yo y del Todo. $\mathrm{Y}$ detuvieron los mil carros de un viaje de siglos al pie de los breñales cargados de nubes, $y$, sintiendo en sus venas el pálpito de los augurios primaverales, procedieron a la invocación ritual de los ancestros, pasearon en hombros al Sabio que ya sólo hablaba por la oquedad de sus huesos, y, teniendo que ungir la tierra con la sangre de una doncella, lloraron todos al inmolar a la Virgen Electa - lloraron todos, clamando su compasión, lacerando sus vestidos, cerrando con lágrimas las secuencias de sus danzas de fecundidad, al pagar el cruento precio exigido para que hubiese un nuevo júbilo de retoños $\mathrm{y}$ de espigas. Lloraron todos..." (p. 12).

El texto alegoriza aquel tiempo primordial, aquel "Illud tempus", en el que tuvo lugar la organización del cosmos; aquella primera primavera en la que se sacrificó una Virgen Electa (29).

El sentido del sacrificio humano debe buscarse en la teoría arcaica de la generación periódica (30). El mito cosmogónico implica muerte ritual de un gigante primordial, de cuyo cuerpo fueron constituidos los mundos, crecen los cereales. El sacrificio es una repetición ritual de la creación, pues el rito es repetición del acto primordial.

Obsérvese cómo es el origen de los cereales lo que se pone en relación con el sacrificio humano; el trigo genera de la sangre y de la carne de la criatura mítica sacrificada ritualmente. De hecho, el sactificio de una nueva víctima humana para la generación de la vida manifestada en la cosecha, persigue la repetición del acto de creación que dio la vida a los granos. El ritual rehace la creación.

La fuerza activa de los cereales se regenera por el retorno al momento inicial de la plenitud cosmogónica.

Pero lo que interesa de este texto es ante todo la esperanza de una regeneración total del tiempo (primavera), evidente en todos los mitos que implican ciclos cósmicos. Todo ciclo comienza de manera absoluta, porque todo pasado y toda "historia" han sido definitivamente abolidos gracias a una reintegración en el caos. Y comienza de nuevo el cosmos. La primavera, según Mircea Eliade "es una resurrección de la vida universal y por consiguiente de la vida humana. Por ese acto cósmico, todas las fuerzas de la creación vuelven a encontrar su vigor inicial. La vida es reconstruida integramente, todo comienza de nuevo; en una palabra, se repite el acto primordial de la creación cosmica, pues toda regeneración es un nuevo nacimiento, un retorno a aquel tiempo mítico en el que apareció por primera vez la forma en que se regenera" (31).

Stravinsky crea su obra con escenas inspiradas por los ritos paganos de los primeros habitantes de Rusia. Musicalmente, La consagración de la primavera tiene las siguientes partes (32): 


\section{Culto de la tierra}

\section{Introducción}

2 Augurios primaverales

3 Danza de los adolescentes

4 Juego del rapto

5 Danza de la primavera

6 Juegos de las tribus rivales

7 Cortejo del Sabio

8 Glorificación de la Tierrr

9 Danza

\section{EI sacrificio}

\section{Introducción \\ 2 Círculos misteriosos de los adolescentes \\ 3 Glorificación de la Electa \\ 4 Evocación de los ancestros \\ 5 Acto ritual de los ancestros \\ 6 Danza sagrada}

La introducción, una pastoral con acentos bárbados, sugiere la naturaleza, que es adorada por el hombre primitivo. Augurios predicen la llegada de la Primavera. La juventud procede a los juegos rituales: el rapto, la Danza de la Primavera y la lucha de las razas rivales. Acompañado por un cortejo salvaje y entusiasta, el Sabio se aproxima; en una danza orgiástica, es glorificada la Tierra.

En la II parte, la juventud circula describiendo círculos mágicos y ensalza a la Virgen elegida para el sacrificio. Después de la invocación a los manes de los antepasados, se ejecutan en su honor los actos rituales, y todos se juntan en una danza sagrada, que comienza la Virgen elegida; esta se abandona a su delirio extático hasta que cae y expira.

Este ballet es de una admirable sencillez melódica: cada una de sus partes no comprende más que dos cortos temas, más sencillos que la más sencilla de las canciones populares, y los cuales son repetidos sin la menor modificación.

La obra es estrenada en París en 1913 con un inaudito escándalo, que Stravinski atribuye a la mala interpretación coreográfica de Nijinsky. Según Vera, la obra como ballet sigue malograda todavía en la década de los 40 por el recuerdo de la absurda coreografía ruso-dalcroziana del estreno, no muy superada por la concepción de Massine en 1920. Por lo tanto, cree que es todavía un ballet por hacer (p. 185).

Vera apunta otra causa del fracaso del estreno, además de la coreográfica: los bailarines:
"Si Nijinsky hubiese contado con bailarines así, su coreografía primera de La consagración de la primavera no hubiese sido el fracaso que fue. Era esto lo que pedía la música de Stravinski: los danzantes de Guanabacoa, y no los blandengues y afeminados del ballet de Diaghilev" (p. 260).

Finalmente, Vera señala otra causa del fracaso del estreno: lo que se necesitaba para su interpretación "era una vuelta al baile popular, espontáneo, visceral, fuente primera de la danza (...) aquella La consagración de la primavera, fallida al nacer por buscarse soluciones intelectuales a lo que podía haberse conseguido acudiendo - no sé- a tradiciones danzarias conservadas, seguramente, por algún pueblo descendiente de los antiguos escitas - acaso aquellos Nartas..." (p. 501). Por eso, Vera sueña con la posibilidad de poner en escena una interpretación basada en "danzas elementales, primitivas, hijas del instinto universal que lleva al ser humano a expresarse en un lenguaje gestual..." (p. 501).

Vera, sobre las partes musicales del ballet, sólo hace un análisis y reinterpretación de la Danza sagrada. Le llama la atención el final, cuando la orquesta se fracciona, rompe con las funciones tradicionales, crea una métrica nueva, ajena a toda periodicidad de acentos, donde los elementos sonoros, vistos en función de elementalidad - los instrumentos vuelven a ser lo que fueron en su expresión primera, en una liturgia tribal: maderas, cobres, tripas, pieles tensas - eran llamados para expresar una enorme pulsión de la tierra:

"Bajo la sangre vertida de la Virgen Electa - en ceremonia agónicamente propiciatoria - habría la Tierra que sacarse las entrañas ante el sol naciente de un nuevo año - de un nuevo ciclo nutricio - para dar sustento a los hombres que, viciendo, procreando y muriendo sobre su faz, la adoraban. Y para que la Tierra fuese propicia a quienes la adoraban en este nuevo año - ni mejor ni peor que muchos años anteriores - los hombres de ahora, semejantes en todo a los de ayer, inmolaban una virgen - 'una más', pensaba acaso el Sabio del cortejo, testigo del paso de las generaciones a quienes durante su larga vida hubiese visto sacrificar, en parecidas primaveras, a tantísimas vírgenes. Ahora, el cuchillo bendecido y guardado en el Arca de los Grandes Ceremoniales se hundiría en la carne de una virgen más, en espera de que con ese asperjamiento rojo pariera la Tierra..." (pp. 186-187).

El contacto con estos mitos - música de Stravinski- lleva a Vera a hacerse ciertas reflexiones: se ve reflejada en la Virgen Electa. Como ella se ve padeciendo una muerte en vida a causa de una Idea (religiosa o política) unida siempre a la existencia de un sacrificio, Idea a la que estaba pagando el tributo de sí misma sin haberla aceptado jamás. 
La sacrificada de la ficción lleva a Vera al convencimiento "de que la sangre era necesaria para el advenimiento fecundo de nuevas primaveras en el mundo" (p. 187) "Volvíase, en el fondo, a una muy vieja noción que nos venía de los tiempos sin historia, anteriores a la Historia y que ahora había resurgido brutalmente, para mí, en la historia de mi época" (p. 187). Vera, al son de la Danza sagrada, intuye una interpretación mítica de la Danza. Sus cabilaciones le han llevado a imaginar un ballet, complemento del primero, que sería, en verdad, el ballet de nunca acabar: "los Dioses no se dan satisfechos con el sacrificio. Piden más". Los hombres, atareados en los trabajos de la siembra y creyendo haber cumplido, no descifran las advertencias de los dioses manifiestas en nubes, pájaros, leños, chisporroteos del invierno, próximo a ser apagado. Y viene la sequía - en otras ocasiones fueron inundaciones - y los adolescentes, los hombres, las mujeres y los ancianos

dicen que es necesario derramar la sangre, nuevamente, para aplacar a los Dioses del Estío, envidiosos, acaso de los Dioses de la Primavera, colmados por dávidas y ofrendas oportunas. $\mathrm{Y}$, para ello, habrá un nuevo sacrificio. Y vendrán las danzas del otoño, y los sueños del invierno de cuyas largas noches salen las hembras empreñadas, y vendrán los Augurios, y volverán a asomar las cabezas los retoños vernales sobre las últimas nieves dormidas al pie de los abetos, y pensarán los hombres que para propiciar los partos de la Primavera, hará falta otro sacrificio. Y se olvidará el pasado sacrificio para organizar uno nuevo, pues buenas razones habrá siempre para ello..."(p. 188).

Pero la música de Stravinsky lleva a Vera, finalmente, a una nueva reinterpretación de la Danza sacrale, finalizada la Segunda Guerra Mundial:

"No. Ahora no veía yo ese desenlace como un rito sacrificial sino como el ascendente rito vernal, propiciador de fecundidad, que debió de ser en sus albores. Las tribus de las Eras-sin-Crónicas, en que el ser humano asũmió la tarea fundamental de sobrevivir y perpetuarse, no eran lo bastante numerosas como para permitirse el lujo de inmolar a una hermosa doncella, de vientre destinado a la proliferación de un linaje” (p. 312).

Por lo tanto, el holocausto debía transformarse en una Danza de la Vida: “...todo vendría preparando el enérgico final, en que una pareja electa se irguiese, victoriosa de pruebas iniciadas, ante los 'círculos de adolescentes', contempladores de una unión decretada por el Anciano del Clan como ofrenda de savias humanas a una tierra ya ahíta de sangres y huesos de antepasados" (p. 312).

Estas reflexiones e interpretaciones de Vera sobre el mito primitivo, van conformando el ballet que imagina. Ella sabe que, en cuanto a escenografía, quedan abiertas todas las posibilidades a partir de la nueva visión sobre el argumento (p. 348). Por eso, se dedica a la búsqueda de bailarines entre la gente del pueblo. Gaspar le ayuda. Y Vera halla que el mito ruso también se reinterpreta en Cuba: en la iniciación abakúa - tradición africana - al evocar la fundación de la Secta, un momodrama culminaba con el sacrificio de una mujer llamada Kasikanekua. Pero la verdad era que la mujer se escabullía a tiempo y quien muere en su lugar era una chiva blanca (p. 260). Incluso Vera encuentra que esta práctica mítica se realiza también en Haití: "la hounzi-Kanzó, o nueva iniciada, vestida de blanco, es inmolada en ritual de sustitución que se cumple con el degüello de una cabra" (p. 260-261). Y se repite en la mitología judía en la persona de "la hija de Jefté (...) sacrificada por su padre para lograr una victoria sobre los Amonitas" (p. 261). $\mathrm{Y}$ en el mito griego de Afrodita halla similitudes cuando "derrama su sangre para librar a Adonis de las tinieblas de una larga noche" (p. 261).

Al final del espectáculo, Vera está convencida de que había visto los ritos más antiguos de la humanidad (p. 261): la danza vertical, danza de saltos de hombres, siempre había acompañado las ceremonias de adoración del sol (p. 259). Y eso es precisamente lo que contempla Vera en el baile arará (33). A partir de ahí se podía realizar "una danza realmente sometida a pulsaciones elementales, primordiales" (p. 262). Así sueña Vera ver realizada la obra: movimientos de brazos, horizontales y verticales, saltos, círculos en torno de algo, marcación de síncopas con talones (p. 311). La danza en su origen primordial (34).

Por eso, Vera quiere realizar en Cuba una interpretación renovada, singular, 'de la obra de Stravinsky (La Rusia pagana remozada en Las Antillas) (p. 374). Los ensayos superan todas las previsiones (p. 412). José Antonio vislumbra una interpretación política del ballet: "Esta pequeña primavera, como augurio de gran consagración" (p. 413).

De esta manera, con el triunfo de la Revolución cubana, nada impide que se represente. Hay un público nuevo (p. 573), y al finalizar la novela, nuevamente Vera recomienza los ensayos del ballet, pues la "consagración" política ya se había realizado. La consagración de la primavera, en Cuba, se realiza musical y políticamente hablando.

Nuestra opinión coincide con Vera Kuteischikova, cuando afirma que el sueño de Vera de montar el ballet en Cuba, se hace realidad gracias a la 
Revolución (35). De ahí la relación que se establece en el texto entre la partitura musical y la Revolución cubana y rusa: Los 33 minutos que conmovieron al mundo de la música, recuerdan los Diez días que conmovieron al mundo (p. 289).

En resumen, en el mito como en las revoluciones es necesaria la sangre, la inmolación de una Virgen Electa. La revolución social exige víctimas, pues es la culminación de una lucha de clases; toda revolución tiene que vencer resistencias de las clases caducas que no van a aceptar el tránsito hacia una nueva "primavera" sino a través de nuevas inmolaciones.

Sobre La consagración de la primavera hemos realizado tres acercamientos: dialéctico, materialista y contextual.

La primera lectura intentó mostrar la característica dialéctica de la novela, "reflejo" del movimiento de la historia contradictoria, heterogénea. La obra representa simbólicamente el desarrollo de la sociedad, pues participa de una concepción esencialmente dinámica. Vivimos en un mundo que cambia: el cambio constituye la ley de la vida. En contraposición con los idealistas que conciben el mundo estático, regido por leyes eternas e inmutables, esta novela postula el cambio como primer principio de la existencia. Y si en la historia siempre se ha presenciado el desarrollo, durante el siglo $\mathrm{XX}$, asistimos a la más profunda conmoción social de la historia, pues se pretende acabar con la "explotación del hombre por el hombre", poner fin a la sociedad de clases, y crear una nueva sociedad libre de la opresión. Sin embargo, la lucha es sangrienta, exige nuevas inmolaciones de Vírgenes Electas, pues la burguesía está empeñada en mantener su "statu quo", conservado durante siglos. Es decir, el siglo XX, y posiblemente parte del XXI, serán los siglos históricos en que se pasará del capitalismo al socialismo.

La segunda lectura se fijó en la naturaleza materialista del texto; materialista, por basarse en razones materiales, objetivas, económicas, en contraposición a las idealistas, subjetivas de la burguesía.

La tercera lectura nos llevó a analizar la novela según un procedimiento de elaboración preferido por Carpentier: la intertextualidad, que concibe la novela como una totalidad. La novela propicia textos, autores, datos históricos, literarios, musicales... que fecundan y completan la historia. La historia de las revoluciones está insertada en otras historias que la explican y la comprenden. En general, esos textos nos sitúan en una época y en una sociedad determinada. Así la historia no se halla aislada, sino en un contexto más amplio que la define y la identifica. Pero esos textos no pueden existir, igualmente, sin la historia que los esclarezca. Todas las inquietudes de la época: literarias, musicales, estéticas, se funden en la obra creando una novela barroca, en la que pugnan grandes fuerzas sociales en escenarios que sufren también esos conflictos. Sin duda alguna, uno de los factores determinantes de su barroquismo es esa apretada urdimbre de contextos en que se mueven los personajes en vivo forcejeo dialéctico con la vida, dando la oportunidad al novelista de volcar su información sobre diversas disciplinas del siglo XX.

Carpentier nos presenta una novela épica que es capaz de mostrar una colectividad en movimiento. Intenta percibir la realidad en toda su hondura. Todos los elementos que, de una u otra forma, en repetición constante, dialéctica, muestran una realidad cambiante , serán ingredientes que bien podrán esperarse en la narrativa del cubano. Con razón piensa que la futura novela no puede ser diacrónica sino sincrónica, es decir, llevar planos paralelos, acciones paralelas, tener al individuo siempre relacionado con la masa que lo circunda, con el mundo en gestación que da razón de su ser.

Esta es la razón por la que, al finalizar la lectura de la novela, da la sensación de que no sólo hemos asistido a la historia de Enrique y Vera, sino que hemos caminado a través de una época con todos sus contextos. Hemos conocido los pensamientos de los personajes, sus aspiraciones, sus ideales y sueños de una época: el siglo XX.

\section{NOTAS}

( 1) Quien desee estudiar en concreto las bases téorico-metodológicas de esta concepción, puede consultar nuestra tesis La consagración de la primavera: Una interpretación materialista-dialéctica de la historia. San José, Universidad de Costa Rica, Sistema de Estudios de Posgrado, 1984, pp. 8-23.

( 2) Cfr. Lucien Goldmann, Para una sociología de la novela (Madrid: Ed. Ciencia Nueva, 1975), pp. 230-231.

( 3) La coherencia no se entiende aquí como algo unitario, homogéneo, simple, sino como la plasmación de la dinámica del mundo, en el cual se perciben procesos de estructuración y procesos de desestructuración, es decir, elementos heterogéneos, complejos, que organizan la obra, logrando la unidad ante la diversidad.

( 4) Este segundo paso de análisis es estudiado en nuestra tesis, Op. cit., pp. 61-116. Aquí sólo analizamos la comprensión de la obra. 
( 5) Alejo Carpentier, El reino de este mundo (Buenos Aires: Librería del Colegio, 1978), p. 167.

( 6) Julia Kristeva desarrolla la noción de la novela como un proceso de encuentros textuales, como un diálogo de múltiples textos, como una intertextualidad. El contexto mayor, envolvente es la cultura de la época. Cfr. Julia Kristeva, El texto de la novela (Barcelona: Lumen, 1974), pp. 15-25. 94.

( 7) Julia Kristeva, Op. cit., p. 94

( 8) V.M. Aguiar e Silva, Teoría de la literatura (Madrid: Gredos, 1972), p. 214.

( 9) R. Bourneuf y R. Ouellet, La novela (Barcelona: Ariel, 1975), p. 51

(10) Cfr. Roland Barthes, El grado cero de la escritura, seguido de nuevos ensayos críticos (México: Siglo XXI, 1978), pp. 205-221.

(11) Alejo Carpentier, La consagración de la primavera, 3 ed. México: Siglo XXI, 1979), p. 11. Desde aquí, las citas de esta narración se indicarán en el texto con el número de la página entre paréntesis.

(12) Cfr. A.J. Greimas, Semántica estructural (Madrid: Gredos, 1976), pp. 28-29.

(13) “...un mensaje o una secuencia cualesquiera del discurso no pueden considerarse como isótopos más que si poseen uno o varios clasemas en común". A.J. Greimas, Op. cit., p. 81. Por clasemas entendemos con Greimas los semas contextuales propiamente dichos. Es decir, las unidades de comunicación, sintagmas o proposiciones más amplias que los lexemas. Ibid., pp. 80-81.

(14) "Una secuencia es una sucesión lógica de núcleos unidos entre sí por una relación de solidaridad: la secuencia se inicia cuando uno de sus términos no tiene antecedente solidario y se cierra cuando otro de sus términos ya no tiene consecuente". Roland Barthes, Análisis estructural del relato (Buenos Aires: Ed. Tiempo Contemporáneo, 1974), p. 25.

(15) "La repetición de un motivo (...) constituye un procedimiento de composición rico en posibilidades (...) Sin embargo, la recurrencia de motivos o de imágenes tiene otras funciones en la novela, de orden dramático o arquitectónico, funciones diversas que se combinan a veces para dar al motivo una pluralidad de sentidos. Cada novela o conjunto de novelas posee su propio sistema de temas y motivos que hay que descifrar". R. Bourneuf y R. Ouellet, Op. cit., pp. 75-76.

(16) El leitmotiv es un térmico musical. Su carácter se observa al analizar musicalmente La consagración de la primave$r a$, de Stravinsky, en donde los temas son repetidos sin menor modificación.

(17) Bourneuf y Ouellet, La novela, p. 183.

(18) Greimas, Semántica estructural, pp. 276-277.
(19) Ferdinand de Saussure, Curso de ligüística general (Buenos Aires: Editorial Losada, 1978), pp. 207-213.

(20) En el ensayo "Problemática de la actual novela latinoamericana", Carpentier explicita su teoría de los contextos, fundamentada en ideas de Sartre. Se trata de que el hombre vive en unas circunstancias precisas y determinadas, y de que su vida es lo que es porque existe una relación vital, dialéctica, entre ese hombre y aquellas circunstancias. Estas son las que forman los contextos de que hablan Sartre y Carpentier. Cfr. Alejo Carpentier, Tientos y diferencias, pp, 17-32.

(21) Carlos Santander, "Lo maravilloso en la obra de Alejo Carpentier", Atenea (Concepción), n 409 (1965), pp. 99-126. Salvador Bueno, "La serpiente..., pp. 201-218. Juan Durán Luzio, Creación y utopía (Heredia: EUNA, 1979), pp. 153-166.

(22) Lev Ospovat, "El hombre y la historia", Alejo Carpentier (La Habana: Casa de las Américas, 1977), p. 225.

(23) Carlos Fuentes, La nueva novela hispanoamericana, pp. 48-58

(24) Octavio Paz, El laberinto de la soledad (México: Fondo de Cultura Económica, 1977), p. 129.

(25) Algunos autores han interpretado sus novelas desde la perspectiva de este mito. Cfr. Leo Pollmann, La 'nueva novela' en Francia y en Iberoamérica (Madrid: Gredos, 1971), p. 129.

(26) Oliver Beigbeder, La simbología (Barcelona: Oikos-tau, 1971). p. 16

(27) Cfr. Esther P. Mocega-González, "La consagración de la primavera... pp. 65-76.

(28) Mario Benedetti, Letras del continente mestizo (Montevideo: Arca Editorial, 1970), pp. 40-41.

(29) Nótese la relación de este mito con el de Ifigenia, la hija de Agamenón y Clitenmestra.

(30) Mircea Eliade, Tratado de historia de las religiones (México: Ediciones Era, 1975), pp. 312-314.

(31) Ibid., p. 283.

(32) Eric Salzman, La música del siglo XX (Buenos Aires: Ed. Víctor Lerú, 1967), pp. 364-365.

(33) Según Carpentier, en Cuba todavía se dan "Supervivencias de animismo, creencias, prácticas muy antiguas...". Cfr. Tientos y diferencias, pp. 21-22.

(34) "Los que conocían la partitura de La consagración de la primavera - gran bandera revolucionaria de entoncescomenzaban a advertir, con razón, que había, en Regla, al otro lado de la Bahía, ritmos tan complejos o interesantes como los que Stravinsky había creado para evocar 
los juegos primitivos de la Rusia pagana". Cfr. Alejo Carpentier, La música en Cuba (México: Fondo de Cultura Económica, 1946), p. 236.

(35) Vera Kuteischikova, "Carpentier ha muerto", p. 94.

\section{BIBLIOGRAFIA}

Aguiar e Silva, V.M. Teoría de la literatura. Madrid: Gredos, 1972.

Arce, Fernando Arturo. Literatura hispanoamericana contemporánea. San José: EUNED, 1982.

Barthes, Roland. El grado cero de la escritura, seguido de nuevos ensayos críticos. México: $\mathrm{Si}-$ glo XXI, 1978.

Análisis estructural del relato. Buenos Aires: Ed. Tiempo Contemporáneo, 1974.

Beigbeder, Oliver. La simbología. Barcelona: Oikos-tau, 1971.

Benedetti, Mario. El escritor latinoamericano y la revolución posible. Buenos Aires: Edición Nueva Imagen, 1974.

Letras del continente mestizo. Montevideo: Arca Editorial, 1970.

Bourneuf, R. y Ouellet, R. La novela. Barcelona: Ariel, 1975.

Bueno, Salvador. "La Serpiente no se muerde la cola", Alejo Carpentier. La Habana: Casa de las Américas, 1977.

Carpentier, Alejo. El reino de este mundo. Buenos Aires: Librería del Colegio, 1978.

México: Siglo XXI, 1979.

La consagración de la primavera.

"Un camino de medio siglo", La novela latinoamericana en vísperas de un nuevo siglo. México: Siglo XXI, 1981.

."La novela latinoamericana en vísperas de un nuevo siglo", La novela latinoamericana en vísperas de un nuevo siglo. México: Siglo XXI, 1981.
"Carta", Casa de las Américas, n. 125 (1981), p. 71.

"Problemática de la actual novela latinoamericana", Tientos y diferencias. Buenos Aires: Calicanto Editorial, 1976.

La música en Cuba. México: Fondo de Cultura Económica, 1946.

Durán Luzio, Juan. "Nuestra América, el gran propósito de Alejo Carpentier", Cuadernos americanos, Vol. 238 (1980), pp. 22-34.

- Durán Luzio, Juan. Creación y utopía. Heredia: EUNA, 1979.

Eliade, Mircea. Tratado de historia de las religiones. México: Ediciones Era, 1975.

Flores, Angel y Silva, Raúl, La novela hispanoamerica actual. New York: Las Américas, 1971.

Fuentes, Carlos. La nueva novela hispanoamericana. México: Joaquín Mortiz, 1980.

Gálvez Acero, Marina. La novela hispanoamericana del siglo XX. Madrid: Ed. Cincel, 1981.

Goldmann, Lucien. Para una sociología de la novela. Madrid: Ed. Ciencia Nueva, 1975.

Greimas, A.J. Semántica estructural. Madrid: Gredos, 1976.

Harss, Luis. Los nuestros. Buenos Aires: Ed. Sudamericana, 1977.

Kristeva, Julia. El texto de la novela. Barcelona: Lumen, 1974.

Kuteischikova, Vera "Carpentier ha muerto", Casa de las Américas, n. 122 (1980), p. 94.

Menton, Seymour "Alejo Carpentier, La consagración de la primavera", Revista Iberoamericana, n. 110-111 (1980), pp. 342-345.

Mocega-González, Esther P. "La consagración de la primavera: La Danza y la Revolución", Hispanic Journal, Vol. 4, n. 2 (1983), pp. 65-76. 
Ospovat, Lev. "El hombre y la historia", Alejo Carpentier. La Habana: Casa de las Américas, 1977.

Paz, Octavio. El laberinto de la soledad. México: Fondo de Cultura Económica, 1977.

Pérez Miguel, Rafael. La consagración de la primavera: Una interpretación materialista-dialéctica de la historia. San José, Universidad de Costa Rica, Sistema de Estudios de Posgrado, 1984.

Picado, Manuel. "En torno a Carpentier", Revista de la Universidad de Costa Rica, n. 41 (1975), pp. 216-217.
Pollmann, Leo. La nueva novela en Francia e Iberoamérica. Madrid: Gredos, 1971.

Salzman, La música del siglo XX. Buenos Aires: Ed. Víctor Lerú, 1967.

Santander, Carlos. "Lo maravilloso en la obra de Alejo Carpentier", Atenea (Concepción), n. 409 (1965), pp. 99-126.

Saussure, Ferdinand de. Curso de lingüística general. Buenos Aires: Editorial Losada, 1978.

Shaw, Donald L. Nueva narrativa hispanoamericana. Madrid: Editorial Cátedra, 1981. 
